\title{
Climate and vegetation changes during the Lateglacial and early-middle Holocene at Lake Ledro (southern Alps, Italy)
}

\author{
S. Joannin ${ }^{1,2,3,4}$, B. Vannière ${ }^{2}$, D. Galop ${ }^{5}$, O. Peyron ${ }^{2}$, J. N. Haas $^{6}$, A. Gilli ${ }^{7}$, E. Chapron ${ }^{8}$, S. B. Wirth ${ }^{7}$, F. Anselmetti ${ }^{9}$, \\ M. Desmet ${ }^{10}$, and M. Magny ${ }^{1,2}$ \\ ${ }^{1}$ MSHE Ledoux, CNRS - USR3124, Besançon, France \\ ${ }^{2}$ Laboratoire Chrono-Environnement, Université de Franche-Comté, CNRS - UMR6249, Besançon, France \\ ${ }^{3}$ LGL TPE, Université Lyon 1, CNRS - UMR5276, Villeurbanne, France \\ ${ }^{4}$ Quaternary Environments and Geoarchaeology, Geography, School of Environment and Development, \\ University of Manchester, Manchester, M13 9PL, UK \\ ${ }^{5}$ GEODE, Maison de la Recherche de l'Université du Mirail, CNRS - UMR5602, Toulouse, France \\ ${ }^{6}$ Institut für Botanik, Universität Innsbruck, Innsbruck, Austria \\ ${ }^{7}$ Geological Institute, ETH Zurich, Zurich, Switzerland \\ ${ }^{8}$ ISTO, Université d'Orléans, BRGM, CNRS - UMR7327, Orléans, France \\ ${ }^{9}$ Institute of Geological Sciences, University of Bern, Bern, Switzerland \\ ${ }^{10}$ GEHCO, Université de Tours, Tours, France \\ Correspondence to: S. Joannin (sebastien.joannin@manchester.ac.uk)
}

Received: 8 November 2012 - Published in Clim. Past Discuss.: 15 November 2012

Revised: 14 March 2013 - Accepted: 15 March 2013 - Published: 9 April 2013

\begin{abstract}
Adding to the on-going debate regarding vegetation recolonisation (more particularly the timing) in Europe and climate change since the Lateglacial, this study investigates a long sediment core (LL081) from Lake Ledro (652 m a.s.l., southern Alps, Italy). Environmental changes were reconstructed using multiproxy analysis (pollen-based vegetation and climate reconstruction, lake levels, magnetic susceptibility and X-ray fluorescence (XRF) measurements) recorded climate and land-use changes during the Lateglacial and early-middle Holocene. The well-dated and high-resolution pollen record of Lake Ledro is compared with vegetation records from the southern and northern Alps to trace the history of tree species distribution. An altitudedependent progressive time delay of the first continuous occurrence of Abies (fir) and of the Larix (larch) development has been observed since the Lateglacial in the southern Alps. This pattern suggests that the mid-altitude Lake Ledro area was not a refuge and that trees originated from lowlands or hilly areas (e.g. Euganean Hills) in northern Italy. Preboreal oscillations (ca. $11000 \mathrm{cal}$ BP), Boreal oscillations (ca. $10200,9300 \mathrm{cal} \mathrm{BP}$ ) and the $8.2 \mathrm{kyr}$ cold event suggest a centennial-scale climate forcing in the studied area. Picea
\end{abstract}

(spruce) expansion occurred preferentially around 10200 and $8200 \mathrm{cal} \mathrm{BP}$ in the south-eastern Alps, and therefore reflects the long-lasting cumulative effects of successive boreal and the $8.2 \mathrm{kyr}$ cold event. The extension of Abies is contemporaneous with the $8.2 \mathrm{kyr}$ event, but its development in the southern Alps benefits from the wettest interval 82007300 cal BP evidenced in high lake levels, flood activity and pollen-based climate reconstructions. Since ca. $7500 \mathrm{cal}$ BP, a weak signal of pollen-based anthropogenic activities suggest weak human impact. The period between ca. 5700 and ca. $4100 \mathrm{cal} \mathrm{BP}$ is considered as a transition period to colder and wetter conditions (particularly during summers) that favoured a dense beech (Fagus) forest development which in return caused a distinctive yew (Taxus) decline. We conclude that climate was the dominant factor controlling vegetation changes and erosion processes during the early and middle Holocene (up to ca. $4100 \mathrm{cal} \mathrm{BP}$ ). 


\section{Introduction}

During the Last Glacial Maximum (LGM) and the earlymiddle Holocene, the vegetation history of the Alpine area records two main features: (1) treeline migration, and the spreading of taxa from various Glacial refugia, in response to long-lasting climate change, and (2) mixed forcing from long- and short-term climate and anthropogenic changes.

During the last orbitally driven deglaciation, conifers and broad-leaved tree species benefitted from global climate improvement and glacier retreat in the Alps to colonise new available areas. A growing body of evidence suggests that these species survived the cold phases in the Po Plain and along the south-eastern Alpine border (Vescovi et al., 2007, 2010; Kaltenrieder et al., 2009, 2010). The spread of Abies, however, may have been different with the possible persistence at high altitudes in the southern slope of the Alps (Hofstetter et al., 2006). To address this question, researchers are searching for studies that meet three criteria: (1) they have to be located in the key zone of south-eastern Alps, which was a potential route for tree immigration from southern Italy and the Balkans and for comparison with the nearby potential Euganean Hills refuge (Kaltenrieder et al., 2009); (2) a palaeovegetational archive must be present at highchronological and temporal resolution for the Lateglacial; (3) and pollen grains must be received from a large range of altitudes in its catchment.

The Holocene climate in Europe is punctuated by numerous short-term cold events, such as Preboreal and Boreal oscillations (Björck et al., 1997, 2001; Fleitmann et al., 2007; Yu et al., 2010), the $8.2 \mathrm{kyr}$ event (Wiersma and Jongma, 2010) and Neoglacial climate cooling at ca. 60004000 cal BP (Magny et al., 2006b; Miller et al., 2010; Giraudi et al., 2011; Zanchetta et al., 2012; Vannière et al., 2012). These rapid climatic changes are recorded throughout the Mediterranean region, but their characteristic effects can vary spatially (e.g. Magny et al., 2003, 2011; Fletcher et al., 2010; Roberts et al., 2011). In the context of low Holocene temperature variations in the Alps $\left( \pm 1^{\circ} \mathrm{C}\right.$; Heiri et al., 2003), precipitation, reflected by lake-level changes (e.g. Magny, 2004), may be a relevant indicator for climate reconstruction at centennial scales. In addition, pollen-based climate reconstructions can enhance our understanding of precipitation changes over the Italian Peninsula (e.g. Peyron et al., 2012). Recent palynological and anthracological records have pointed out the need to disentangle climate and human influences (e.g. Tinner et al., 2003; Valsecchi et al., 2008, 2010; Cruise et al., 2009; Vannière et al., 2011). In the open debate to assess the possible relationships between climatic change and impact of human societies, which has become a contemporary issue, palaeoenvironmental records are needed to gain a perspective of past processes.

In this study we investigate well-dated and high-resolution pollen-based vegetation changes recorded in a long sediment core (LL081) from Lake Ledro (652 m a.s.l., southern Alps,
Italy, Fig. 1). This lake combines the required characteristics (close to the Euganean Hills refuge, relatively large catchment area $\left.\left(111 \mathrm{~km}^{2}\right)\right)$ and offers the opportunity to explore spatial expansion of tree species during the Lateglacial and the early-middle Holocene. We compare the pollen record with proxies that are indicative of run-off, soil erosion and lake level changes (Magny et al., 2009, 2012). Therefore, we provide a complete analysis of climate and anthropogenic activities in the Ledro catchment to assess whether the environment responded to millennial- and centennial-scale climate changes and/or to possible land-use dynamics. This study provides a low temporal resolution for the early Lateglacial (higher in the upper part) as the focus is on the Holocene record. The younger parts of the sequence, characterised by strong human impacts on the vegetation, will be presented in a separate paper dealing with late Holocene environmental changes in the Ledro area.

\section{Study area}

Lake Ledro (Lago di Ledro; $45^{\circ} 52^{\prime} \mathrm{N}, 10^{\circ} 45^{\prime} \mathrm{E}, 652 \mathrm{~m}$ a.s.l.) is a $3.7 \mathrm{~km}^{2}$ large lake located in northern Italy (Fig. 1a), on the southern slope of the Alps (Fig. 1b). The maximum depth of this lake is $46 \mathrm{~m}$. The catchment area is $111 \mathrm{~km}^{2}$ and includes mountains that culminate at 1500-2250 m (Fig. 1c). The geological substratum comprises mainly Triassic, Liassic and Cretaceous limestone. Morainic tongues and conglomeratic deposits of calcareous and siliceous composition fill the valley bottom. The lake was formed due to a morainic dam (Beug, 1964), which is now cut by the outlet. Lake Ledro drains into nearby Lake Garda (65 m a.s.l). Lateglacial and Holocene sedimentation is dominated by calcite precipitation and biogenic lake productivity accompanied with allochthonous material, such as clay and organic particles.

Vegetation around the lake is dominated by beech $(\mathrm{Fa}$ gus) mixed with fir (Abies). Higher in the Ledro Valley, the montane belt $(650-1600 \mathrm{~m})$ is characterised by spruce (Picea). The subalpine belt (1600-2000 m) is dominated by Larix (larch) and Picea, and is replaced by grasslands above $2000 \mathrm{~m}$. The mild climate allowed for the development of (1) a mixed oak forest with lime (Tilia) and elm (Ulmus) trees, and (2) Mediterranean vegetation such as Quercus ilex, Ericaceae and olive trees, which can reach $300 \mathrm{~m}$ a.s.l. as a grove forms. At Molina di Ledro, a village at the Lake Ledro outlet, the mean temperature of the coldest and warmest months are 0 and $20^{\circ} \mathrm{C}$, respectively. The annual precipitation ranges from ca. 750 to ca. $1000 \mathrm{~mm}$.

\section{Methods}

\subsection{Selection of the coring site}

Lake Ledro bathymetry (Fig. 2a) and sedimentary stratigraphy have been documented by a high-resolution seismic 


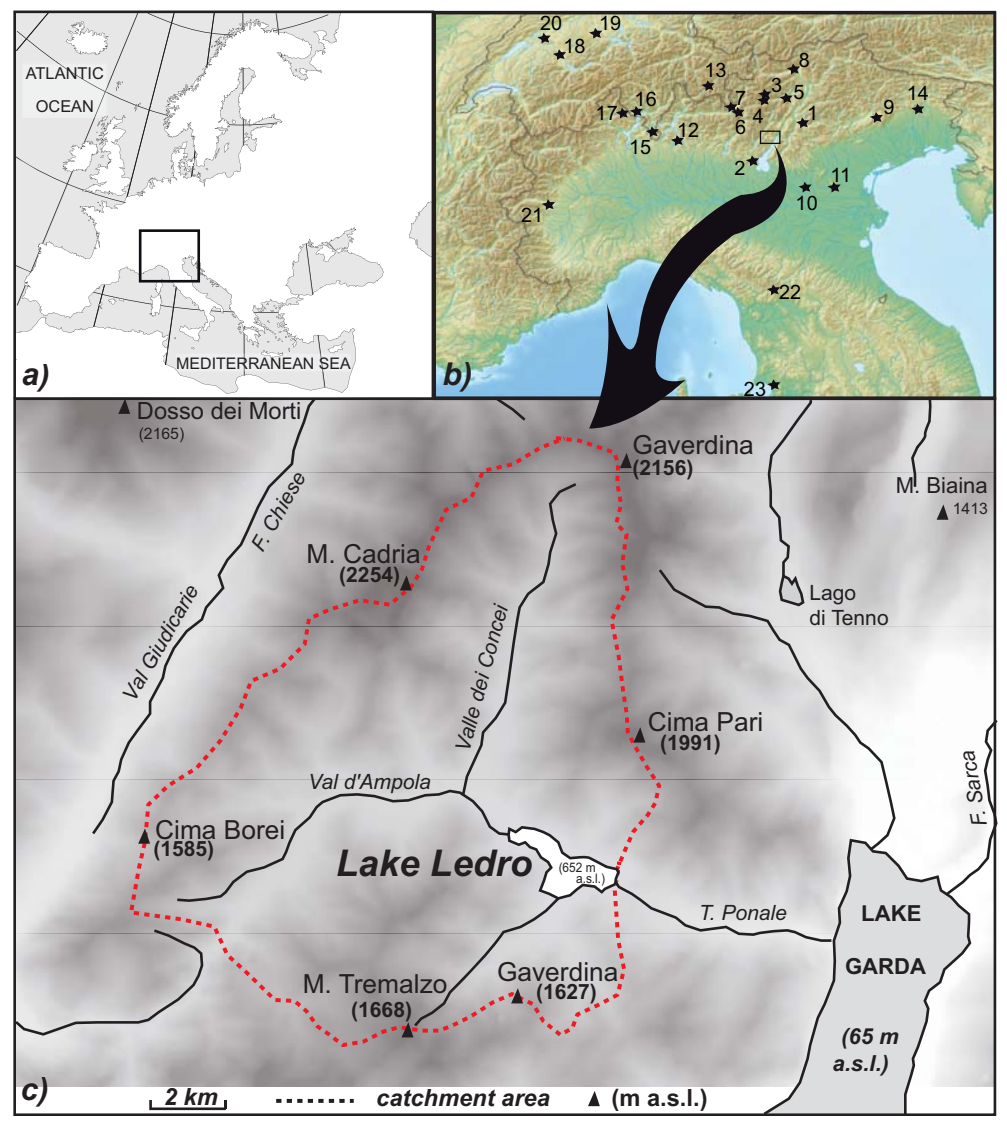

Fig. 1. (a) The study site in the northern Mediterranean area. (b) Location of pollen sites discussed in the paper for the Alps and northern Italy - 1: Lake Lavarone (Filippi et al., 2007); 2: Lake Lucone (Valsecchi et al., 2006); 3: Passo del Tonale (Gehrig, 1997); 4: Valle di Sol (Favilli et al., 2010); 5: Lake Tovel (Gottardini et al., 2004); 6: Palù di Sonico (Gehrig, 1997); 7: Pian di Gembro (Pini, 2002); 8: Totenmoos (Heiss et al., 2005); 9: Palughetto Cansiglio Plateau (Vescovi et al., 2007); 10: Lago di Fimon (Valsecchi et al., 2008); 11: Lago della Costa (Kaltenrieder et al., 2009, 2010); 12: Lago di Annone (Wick and Möhl, 2006); 13: Lej da San Murezzan (Gobet et al., 2003); 14: Lago Ragogna (Monegato et al., 2007); 15: Lago di Origlio (Tinner et al., 1999); 16: Balladrum (Hofstetter et al., 2006); 17: Piano (Valsecchi and Tinner, 2010); 18: Gerzensee (Lotter et al., 2000); 19: Soppensee (Lotter, 1999); 20: Lobsigensee (Tinner and Vescovi, 2005); 21: Lago Piccolo di Avigliana (Finsinger et al., 2006); 22: Lago del Greppo (Valsecchi et al., 2010); 23: Lago dell'Accesa (Drescher-Schneider et al., 2007). (c) Catchment area of Lake Ledro (dotted line).

reflection survey using a $3.5 \mathrm{kHz}$ pinger source and an Octopus Marine acquisition system mounted on an inflatable boat. Conventional GPS navigation allowed tracking the acquisition of a dense grid of profiles imaging most of the basin fill (Fig. 2a and b; Simonneau et al., 2013). To encompass the entirety of Holocene sediments, coring site LL081 was selected in the deep basin, away from chaotic to transparent lens-shaped bodies reflecting mass wasting deposits (MWD) and in a relatively distal position from the two main deltas formed by lake tributaries. The coring site was characterised by well-stratified, acoustic facies showing continuous and high-frequency reflections (Fig. 2b).

\subsection{Core sampling and sedimentology}

Coring recovery was done using an UWITEC coring platform with a percussion piston coring technique. Coring operations were directly guided by the quasi-3D seismic stratigraphy. Twin cores were retrieved, and segments were extracted and stored at $4{ }^{\circ} \mathrm{C}$ at the University of FrancheComté (France).

The cores were split longitudinally into two halves, photographed and logged with a GEOTEK Multi-Sensor Core Logger to obtain geophysical measurements (gamma-ray wet bulk density, magnetic susceptibility - MS, $p$ wave velocity) at $5 \mathrm{~mm}$ intervals. The master core (MC), i.e. the ideal and complete lithologic succession using both parallel cores, was established based on lithological changes (with observation of key reference horizons) in combination with MS and gamma-density profiles.

MS, primarily dependent on the magnetite concentration in sediments, was measured in electromagnetic units to determine the inorganic allochthonous sediment content (Gedye et al., 2000). The development of pedogenesis under forest 


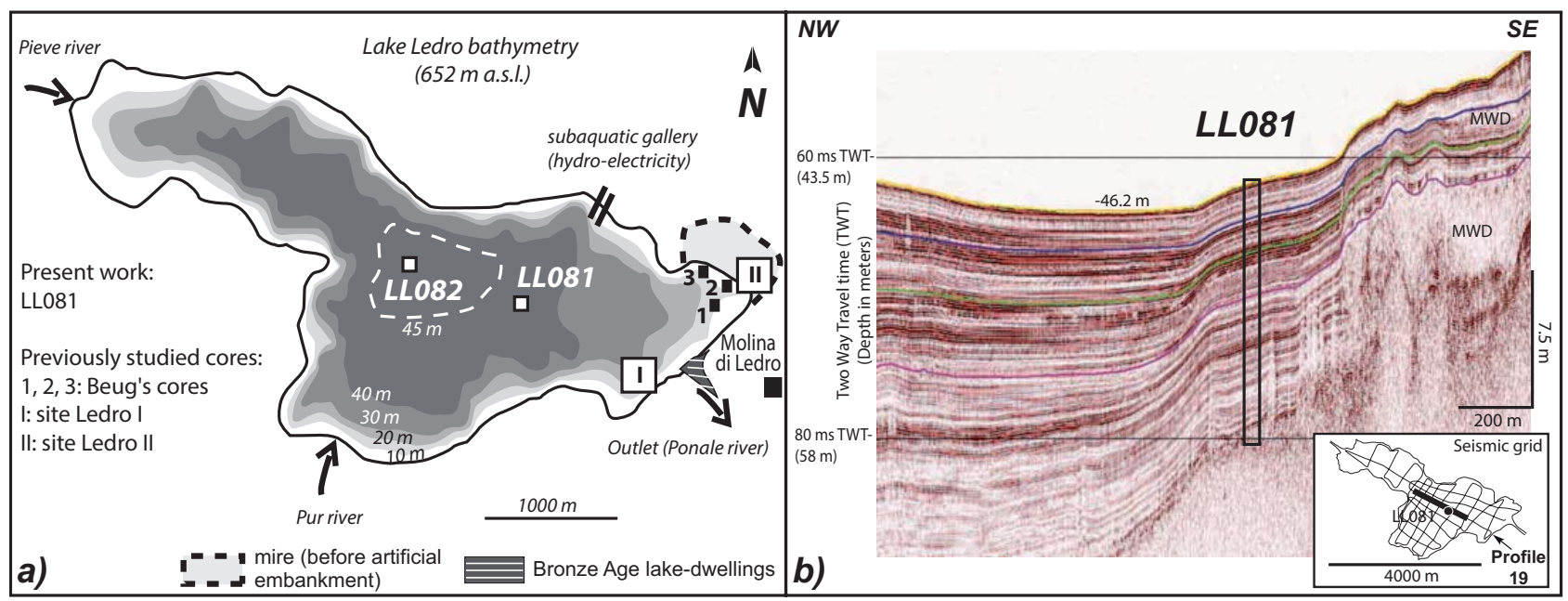

Fig. 2. Main characteristics of the Lake Ledro basin fill: (a) Lake Ledro bathymetry showing the Pieve and Pur River deltas, and collection location of the LL081 (this study) and LL082 (Simmoneau et al., 2012; Vannière et al., 2012) sediment cores and of previously studied sites from Beug (1964) (1-3) and Magny et al. (2009) (I-II); (b) seismic reflection profile from Lake Ledro illustrating well-preserved basin fill geometry at site LL081, i.e. away from tributary deltas and mass wasting deposits (MWD).

cover may have favoured a mineral magnetic increase in soils (Jong et al., 1998), so low MS in sediments is expected during phases of stabilised, vegetated slopes (Whitlock et al., 2011), while increased magnetic concentrations may be related to changes in sediment sources and soil erosion (Dearing et al., 1996; Jong et al., 1998; Vannière et al., 2003; Cruise et al., 2009). Nevertheless, when ferrimagnetic mineral concentration is low (magnetite and maghaemite), MS may be largely influenced by diamagnetic minerals (quartz, carbonates) (Thompson and Oldfield, 1986).

$\mathrm{X}$-ray fluorescence core scanning was done on an AVAATECH instrument at the ETH Zurich and with a spatial resolution of $200 \mu \mathrm{m}$. XRF core scanning is a fast, non-destructive technique which provides information about elemental variations directly from untreated sediment and reflects proportions of different minerogenic components (Löwemark et al., 2011). Among the various elements tested (Vannière et al., 2012), and considering the geological setting of the catchment, we provide the $\mathrm{Ca} / \mathrm{Si}$ ratio to distinguish between authigenic carbonate sedimentation from glacial face leaching, mostly comprising siliceous stones transported by the glacial tongue in the valley. $\mathrm{Ca}$ and $\mathrm{Si}$ were thus anticorrelated $(r=-0.55 ; p$

$,<0.001)$. A Ca/Si ratio increase was interpreted to correspond to an increasing authigenic carbonate component linked with climate warming and/or to a lower siliceous proportion under decreasing run-off and humidity.

\subsection{Radiocarbon dating}

The Lateglacial and early-middle Holocene chronology is based on six accelerator mass spectrometry (AMS) ${ }^{14} \mathrm{C}$ ages measured on terrestrial organic material from cores
LL081 (Table 1). Four ${ }^{14} \mathrm{C}$ ages measured on a different core (LL082, Fig. 2a) are included according to lithological correlation (Vannière et al., 2012). Macrofossils were collected from sediment samples sieved with a $100 \mu \mathrm{m}$ mesh screen. Radiocarbon ages were calibrated in yrcal BP by the Calib 6.0 software using the calibration curve IntCal09 (Reimer et al., 2009). Dates are expressed as intercepts with $2 \sigma$ ranges. Further age control is provided by the Lateglacial-Holocene transition $(\sim 11700 \mathrm{yr}$ cal BP), which is well established in the LL081 pollen stratigraphy. This transition is also observed in the littoral site of Ledro II, where it is dated to $10090 \pm 70 \mathrm{BP}$, i.e. $11700-11240 \mathrm{cal} \mathrm{BP}$ (Fig. 2a; Magny et al., 2012). Therefore, we used this transition to better constrain the age-depth model. The agedepth model is constructed using a smooth, cubic spline model (Fig. 3) available within the "Clam" software from Blaauw (2010).

\subsection{Pollen analysis}

\subsubsection{Pollen samples}

Sediment samples $\left(1 \mathrm{~cm}^{3}\right)$ were treated both chemically ( $\mathrm{HCl}, \mathrm{KOH}, \mathrm{HF}$, acetolysis) and physically (sieving) following standard procedures (Moore et al., 1991). Lycopodium spore tablets were added for estimating pollen concentrations (grains $\mathrm{cm}^{-3}$; Stockmarr, 1971). Pollen grains were poorly preserved in the lower part of the LL081 core. A total of 124 pollen samples were analysed under a light microscope at standard magnification $(\times 400)$. A total of 123 pollen types were identified using photo atlases (Reille, 1992-1998; Beug, 2004) and the reference collection at the University of Franche-Comté. 
Table 1. AMS radiocarbon dates with a $2 \sigma$ age range calibration from the Lake Ledro LL081 core.

\begin{tabular}{lllrlr}
\hline Sample ID & Lab. code & Material & $\begin{array}{r}\text { AMS 14C } \\
\text { Age BP }\end{array}$ & $\begin{array}{l}\text { Depth MC } \\
(\mathrm{cm})\end{array}$ & $\begin{array}{r}\text { Cal yr BP } \\
(2 \sigma)\end{array}$ \\
\hline B2a-43* & ETH-40411 & Leaf remains & $3575 \pm 35$ & 424.9 & $3730-3980$ \\
B2a-80 & POZ-27891 & Wood charcoal & $4080 \pm 35$ & 461.6 & $4440-4810$ \\
A3b-91 & POZ-30223 & Wood charcoal & $4550 \pm 35$ & 499.2 & $5050-5320$ \\
A3b-127* & ETH-39233 & Leaf remains, needles & $5200 \pm 35$ & 535.8 & $5900-6170$ \\
B2b-20 & POZ-27892 & Wood charcoal & $5720 \pm 40$ & 562.4 & $6410-6630$ \\
A4a-19* & ETH-39234 & Needles & $6530 \pm 40$ & 589 & $7330-7560$ \\
A4a-46 & POZ-30224 & Wood charcoal & $7270 \pm 50$ & 616 & $7980-8180$ \\
B2b-109 & POZ-27894 & Wood charcoal & $8385 \pm 35$ & 641.5 & $9300-9490$ \\
A4a-73* & ETH-39235 & Needles & $8405 \pm 40$ & 643 & $9300-9520$ \\
B3a-75 & POZ-27895 & Wood charcoal & $11480 \pm 60$ & 759.3 & $13200-13470$ \\
\hline
\end{tabular}

* Ages obtained from core LL082 and lithologically correlated.

As the dominant taxa can reduce the significativity of the other taxa counted, we constantly counted a minimum of 300 terrestrial pollen grains excluding the most dominant terrestrial taxa as well as water and wetland plants, and pteridophyte spores. Therefore, the dominant taxa were successively Pinus, Corylus and deciduous Quercus. During the calculation process, terrestrial pollen percentages were calculated based on total pollen (i.e. including all terrestrial taxa), which is on average 706 grains per sample. Spores and algae were added to the total counted palynomorphs to calculate their percentage.

Using the TILIA 1.12 program (Grimm, 1992-2005), main pollen percentages are represented in Fig. $4 \mathrm{a}$ and b. Local pollen assemblage zones (LPAZ) were defined using the CONISS function of TILIA 1.12 (Tables 2 and 3). One solid and eight dashed lines define the limits between statistical first- and second-order splits. Figure 5 presents a pollen diagram with selected major arboreal and non-arboreal taxa and the sum of anthropogenic indicators. Two ratios were established: total arboreal taxa $\left(\mathrm{AP}_{\mathrm{t}}\right)$ and arboreal pollen without Pinus $\left(\mathrm{AP}_{\mathrm{wp}}\right)$.

\subsubsection{Pollen-based climate reconstruction}

The modern analogue technique (MAT; Guiot, 1990) was used to reconstruct climatic changes in the Mediterranean area (e.g. Davis and Brewer, 2009; Joannin et al., 2011; Peyron et al., 2011; Combourieu Nebout et al., 2013). MAT is based on a modern pollen dataset containing more than 3500 modern spectra, with 2000 samples from the Mediterranean area (Dormoy et al., 2009). To reduce uncertainties, we have applied to the analogues selection a constraint by biomes (Peyron et al., 1998). The biomes assigned to the selected modern analogues are compared to the biome assigned to the fossil assemblage, and only the analogues with consistent biomes are retained for the analogue matching step. Additional information about MAT methodology and its application to the Ledro pollen record are available in the work by
Peyron et al. (2012). Annual precipitation was reconstructed based from the pollen dataset (dashed line in Fig. 5).

\section{Results and interpretation}

\subsection{Age model and sediment lithology}

\subsubsection{Age-depth model}

Age control during the Lateglacial is inferred from one radiocarbon date which permits the extension of the age model (Fig. 3) to the Younger Dryas and the beginning of the Holocene. The age-depth model is extrapolated to the base of the mastercore so that these ages might just be used as estimation.

The age-depth curve shows low sedimentation rates from the beginning of the Holocene to ca. $7000 \mathrm{yr}$ cal BP, resulting in condensed deposits from 7 to $5.75 \mathrm{~m}$ depth. The average temporal resolution is approximately $73 \mathrm{yr} / \mathrm{sample}$ for this portion of the core. Sedimentation rates increase steadily upwards in the core. The average temporal resolution for the upper part is estimated to $77 \mathrm{yr} / \mathrm{sample}$.

\subsubsection{Changes in lithological and abiotic proxies}

Changes in the abiotic proxies (MS, Ca/Si; Fig. 5) suggest phases with distinct sediment sources and erosive processes, and strong contrast between multi-millennial trends, which can be unravelled from the data. While $\mathrm{Ca}$ is related to authigenic carbonate component, $\mathrm{Si}$ is related to detrital inputs. Three phases are distinguished.

From the base up to ca. $10800 \mathrm{cal} \mathrm{BP}$, increasing Ca/ Si ratio suggests high but decreasing erosional activity, while relatively stable MS values do not indicate soil erosion in the not yet afforested area. From up to approximately $5700 \mathrm{cal}$ BP, MS values are stable and low, suggesting that erosion was low. From ca. 5700 to $4100 \mathrm{cal} \mathrm{BP}$, coinciding peaks and 


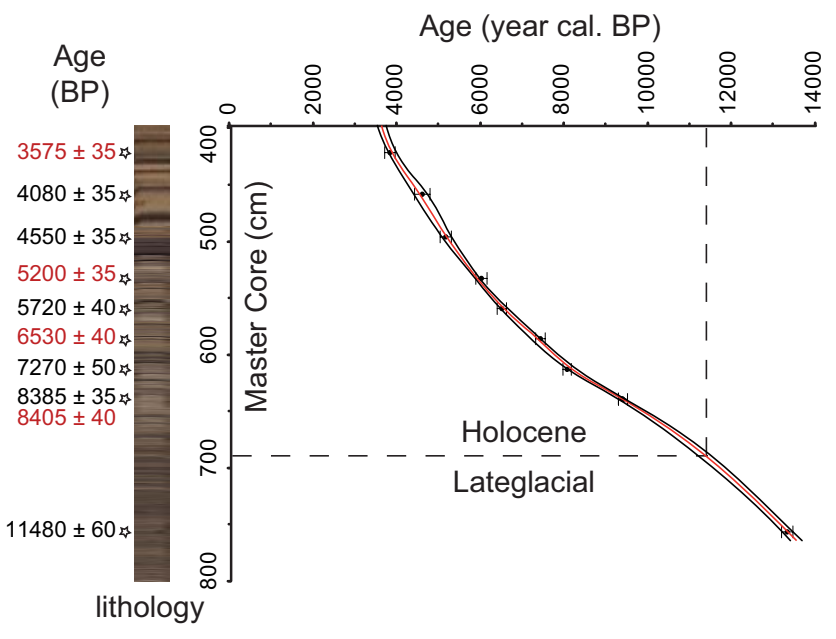

Fig. 3. Lithology of the mastercore LL081 and age-depth model based on calibrated radiocarbon ages (black dots with $2 \sigma$ errors) (AMS, see Table 1) from LL081 and LL082 (in red).

drops in $\mathrm{MS}$ and $\mathrm{Ca} / \mathrm{Si}$ (at ca. 5500 and $5000 \mathrm{cal} \mathrm{BP}$ ) are observed.

While core lithology did not reveal multi-millennial trends, carbonate marl facies (white to brown in colour) were intercalated with detrital material layers (dark colours) (Fig. 3; for further detail, see Simonneau et al., 2013). This pattern is obvious from two thick, dark detrital layers of 23 and $12 \mathrm{~cm}$ dated at ca. 5500 and $5000 \mathrm{cal} \mathrm{BP}$, respectively. All abiotic proxies shift in these layers, which are interpreted as the signature of two exceptional, most likely short-term, flood events discharging elements from soil and rocks and eventually diluting the pollen concentration (Fig. 5). This scheme suggests continuous sedimentation of authigenic carbonate, sporadically interrupted by detrital events (Vannière et al., 2012; Simonneau et al., 2013).

\subsection{Pollen analysis}

\subsubsection{Pollen sequence and terrestrial vegetation dynamics}

The history of Lake Ledro vegetation is divided into four LPAZ for the Lateglacial (LL-1 to LL-4) and two LPAZ (LL5 and LL-6) with lower level subdivisions for the Holocene (Fig. 4a and b). Only general features could be identified in the three first LPAZ (LL-1 to LL-3) because samples with sufficient pollen grains are sparse.

According to the age model, the sequence starts around $17000 \mathrm{cal}$ BP (LL-1). The pollen record suggests that a mixed open forest may have grown in the Lake Ledro landscape (Table 2), which was dominated by Pinus (pine) trees (ca. 60\%) and consist of pioneer vegetation (Betula, Juniperus and Ephedra). Artemisia, Chenopodiaceae and Poaceae developed in a steppe tundra, most likely located at a higher altitude. Rare grains of deciduous Quercus, Corylus and
Salix exemplify the regional presence of temperate trees at the end of the LGM and the following Lateglacial (LL-1 and LL-2), when climate was still cold and arid and the Alpine glaciers were still in proximity.

From ca. $14100 \mathrm{cal}$ BP (zone LL-3, Table 2), polleninferred vegetation around Lake Ledro indicates a change in the woody taxa composition, illustrated by $\mathrm{AP}_{\mathrm{wp}}$ increase (up to $60 \%$ ). This change includes development of thermophilous trees (deciduous Quercus and Corylus) and mixed open and mixed coniferous forests (Betula, Pinus, and Larix) during the Aller $\varnothing \mathrm{d} / \mathrm{B} \varnothing 1$ ling interstadial. Ulmus, Tilia, and Fraxinus excelsior also appeared in the pollen record, together with Abies which develops in the montane belt. Considering the poor dispersal of Abies (fir) pollen grains (Mazier, 2006) and diversity of thermophilous taxa at the end of this zone, the Lake Ledro landscape likely was below the treeline.

In zone LL-4 (ca. 12700 to ca. 11700 cal BP), Betula, Pinus and Larix redeveloped, while the amount of deciduous Quercus, Abies, Ulmus and Tilia decreased. Forest spread therefore ceased (low values of $\mathrm{AP}_{\mathrm{wp}}$ ), and steppe and meadows increased (up to $10 \%$ each). These patterns illustrate climate deterioration in the Younger Dryas (YD). Only coniferous woods (Pinus and Larix) seem to develop at the lake elevation. During this phase, abundant Volvocaceae (HdV-128) are recorded, typical for an open but less deep lake than today (Jouffroy-Bapicot, 2010).

At ca. 11700 cal BP (zone LL-5), rapid increases in deciduous Quercus and Ulmus correspond to local settlement of a thermophilous forest. The sharp increase in $\mathrm{AP}_{\mathrm{wp}}$ thus suggests an upward migration of the treeline added to the effect of rapid climate improvement at the beginning of the Holocene. The pollen record shows high and low Pinus amount before and after $650 \mathrm{~cm}$ (ca. $9800 \mathrm{cal} \mathrm{BP}$ ), respectively.

The CONISS clustering method identifies two subzones (Table 2). The first (LL-5a; ca. 11000 to ca. 10350 cal BP) is characterised by abundant deciduous Quercus (oak) pollen grains and relatively abundant Ulmus (elm), Corylus (hazel) and Tilia (lime) pollen grains. This expansion is associated with birch development, most likely on the lake shore, as suggested by higher Betula pollen rates in the littoral core from Ponale (Magny et al., 2012) than in deep sediments. Corylus and Fraxinus excelsior population expansion is delayed by $350 \mathrm{yr}$ compared to the concomitant increase in deciduous Quercus, Ulmus and Tilia. Sharp decreases in Pinus $(\Delta 20 \%)$ and deciduous Quercus, Ulmus and Corylus occurred at ca. $11200 \mathrm{cal} \mathrm{BP}$ and in the subsequent samples (ca. 11000 to ca. $10800 \mathrm{cal} \mathrm{BP}$ ), respectively.

In subzone LL-5b (ca. 10350 to ca. $9750 \mathrm{cal} \mathrm{BP}$ ), the $\mathrm{AP}_{\mathrm{wp}}(\sim 87 \%)$ suggests a dense, mixed oak forest progressively dominated by Corylus (up to $34 \%$ ). A marked decrease in Pinus (pine) begins at the Preboreal-Boreal transition (ca. $10800 \mathrm{cal} \mathrm{BP}$ ) and continues during the Boreal phase. Despite the proximity of the Mediterranean belt, 
Table 2. Inventory of local pollen zones with depth and estimated ages, main taxa, total arboreal pollen (AP), and common and rare pollen types. Note that two ratios $\left(\mathrm{AP}_{\mathrm{t}}\right.$ and $\left.\mathrm{AP}_{\mathrm{wp}}\right)$ are used - arboreal pollen without Pinus $\left(\mathrm{AP}_{\mathrm{wp}}\right)$ was calculated by excluding Pinus (pine) pollen grains.

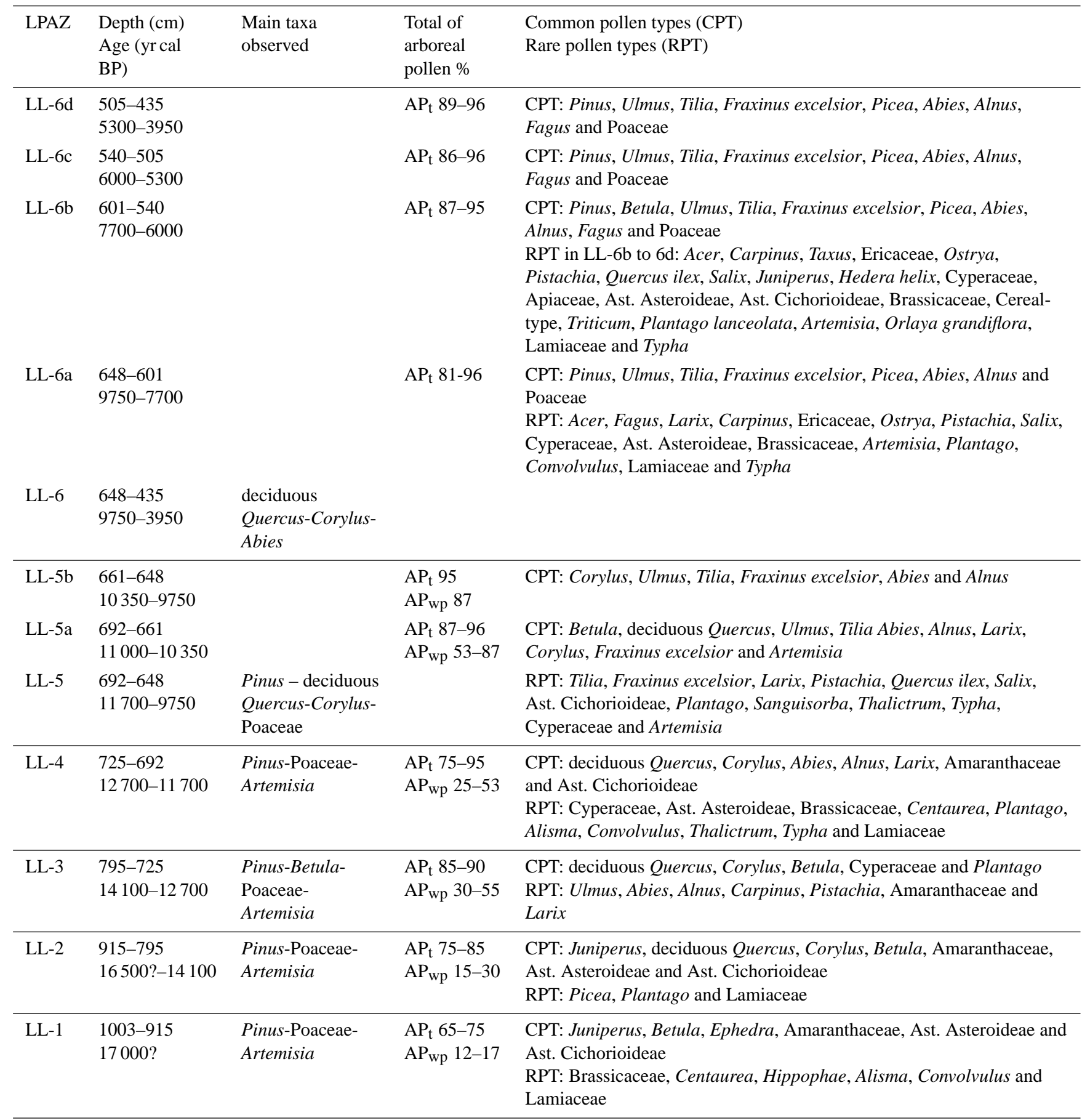

sclerophilous taxa (Quercus ilex type) appearing in the zone LL-5b are scarce (which is the case until the top of the sequence).

From ca. 9750 to 3950 cal BP, deciduous Quercus, Ulmus, Corylus, Tilia, Fraxinus excelsior, Acer, Picea, Abies,
Alnus, Taxus, Fagus and Carpinus successively developed, regressed and replaced each other. As a result a remarkably stable plateau in AP values (between 81 and $96 \%$; LL-6) is observed. The CONISS function groups the four subzones (LL-6a-b-c-d). 
Lake Ledro

selected pollen types, $\%$ values

exaggeration $\times 10$

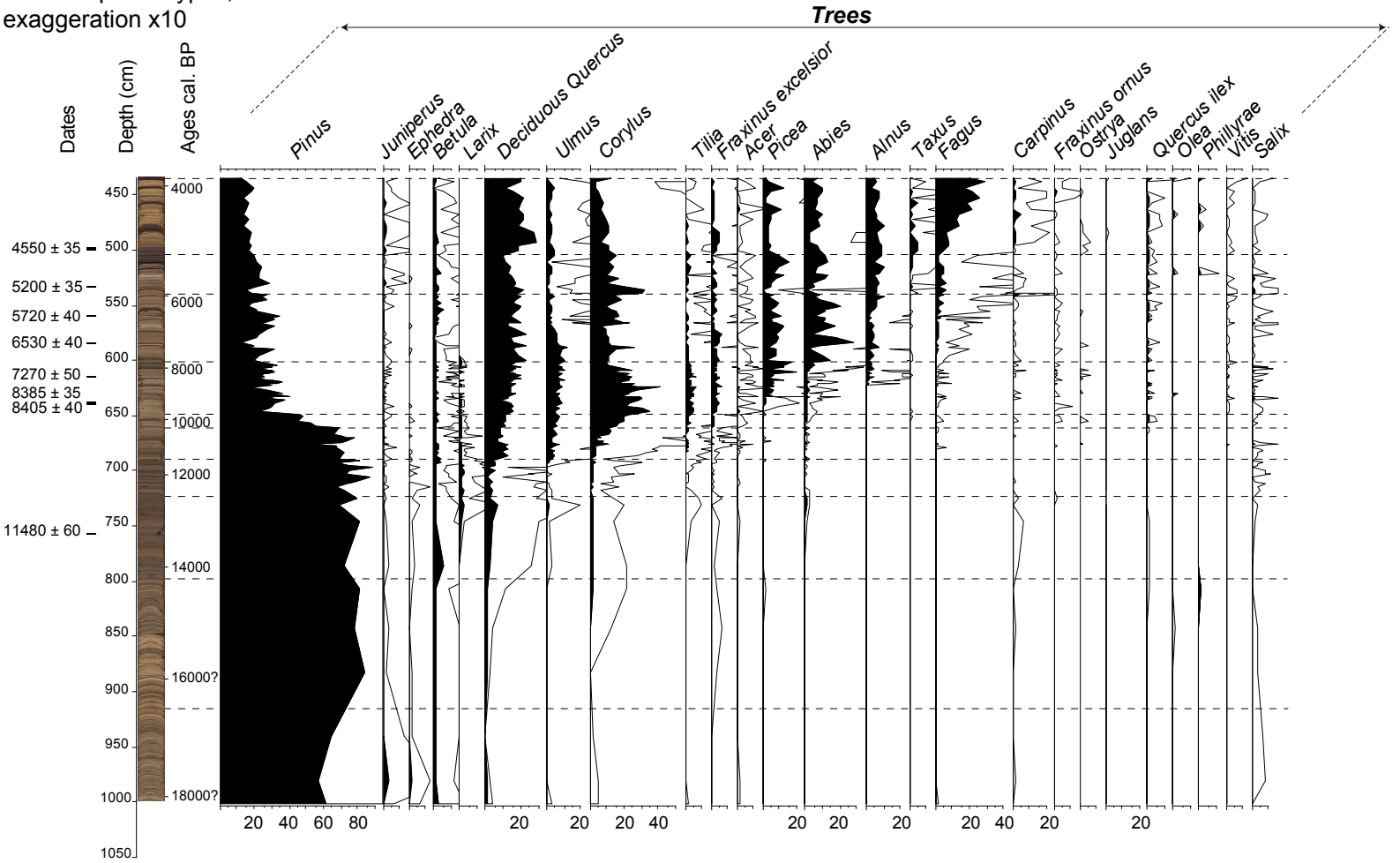

\section{Lake Ledro}

selected pollen types, \% values exaggeration $\times 10$

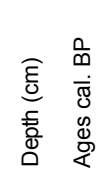

$$
\text { x10 }
$$


Subzone LL-6a (ca. 9750-7700 cal BP) is characterised by the Picea development (up to 20\%), the appearance of Abies pollen grains, steady increases in deciduous Quercus and Ulmus and decrease in Corylus percentage. The decline in Corylus and Tilia correlates with the Picea main increase, and, when focussing on short oscillations, opposed percentage variations of Corylus and Picea are recorded $(\Delta 20 \%$ and $\Delta 15 \%$, respectively). Since ca. 9750 cal BP, temperate trees and shrubs developed and formed a mixed deciduous oak forest (Table 3). More specifically, deciduous Quercus, Ulmus, Picea and Corylus mainly composed the pollen assemblage from ca. 9750 to ca. $7700 \mathrm{cal} \mathrm{BP}$.

The first Abies maximum at ca. $7700 \mathrm{cal} \mathrm{BP}$ and the gradual increase in the abundance of Fagus mark the beginning of subzone LL-6b (up to ca. 6000 cal BP). Sharp variations in the percentage of Abies pollen are recorded with a maximum $(25 \%)$ at ca. $7200 \mathrm{cal} \mathrm{BP}$. The pollen diagram from the littoral section of Ponale (Magny et al., 2012) provides an earlier presence of Alnus than the deep core. This may indicate that this taxa was living around the lake margin before entering the forest composition, as shown by its rapid immigration and development in subzone LL-6b. Between ca. 6700 to ca. 6000 cal BP, Tilia, Ulmus and Fraxinus excelsior regressed, while Corylus re-expanded. On shorter time scales, lows in the percentages of Picea and Abies are observed concomitantly with an important increase in Corylus at ca. $6700 \mathrm{cal} \mathrm{BP}$ and ca. $6000 \mathrm{cal} \mathrm{BP}$. Cereal-type pollen grains are first recorded at ca. $7500 \mathrm{cal} \mathrm{BP}$, suggesting human activity in the Ledro landscape.

The subsequent subzone LL-6c (ca. 6000 to ca. 5300 cal BP) starts with a near disappearance of Picea pollen (at ca. $5950 \mathrm{cal}$ BP) and an increase in Taxus. Deciduous Quercus decreases to a minimum of $10 \%$. The AP rate is slightly lower than that of previous LL-6 subzones as reductions in temperate and coniferous trees are balanced by increased Artemisia, Poaceae and Asteraceae Cichoriodeae.

From ca. 5300 to ca. $3950 \mathrm{cal}$ BP (LL-6d), the pollenbased vegetation is characterised by large amounts of deciduous Quercus and Abies and decreases of Corylus and Picea, while Fagus develops up to a maximum $(\sim 30 \%)$ and Carpinus becomes more present. Human occupation is suggested by the presence of cereal-type pollen grains and a questionable apparition of Juglans (which has been collected in northern Italy since the Early Neolithic; Rottoli and Castiglioni, 2009).

\subsubsection{Pollen-based quantitative reconstruction of precipitation}

Annual precipitation has been reconstructed for the interval of ca. 12200 to ca. $4000 \mathrm{cal} \mathrm{BP}$ (Fig. 5) and shows a longterm progressive increase $(\Delta 300 \mathrm{~mm})$. Plurisecular variations also appear to be superimposed on this millennial-scale trend, such as a dry phase which begins during the YD and ends at ca. $11100 \mathrm{cal}$ BP and two drought phases at ca. 91008900 and $8100-7500 \mathrm{cal} \mathrm{BP}$.

\section{Discussion}

\subsection{Pollen-based vegetation dynamics at Ledro and in northern Italy}

\subsubsection{Vegetation changes before and during the Lateglacial interstade}

To assess whether long-distance-transported pollen grains influenced the pollen record of Lake Ledro in LL-1 and LL2 (Table 3), the results were compared with other pollen sites in the southern Alps. Kaltenrieder et al. (2009) observed that the Po Plain lowlands (i.e. below $800 \mathrm{~m}$ a.s.l.) were partly wooded by mixed deciduous conifer woods since the last Glacial and even during the LGM (i.e. 23 to $18 \mathrm{kyr}$ cal BP). We can thus consider that rare pollen grains from mesothermic plants found at Lake Ledro, such as deciduous Quercus, Corylus and Fraxinus excelsior, possibly originated from these lowlands (up to the altitude of the lake, i.e. $652 \mathrm{~m}$ a.s.l.) during the Lateglacial. At the Palughetto basin (1040 m a.s.1.), Vescovi et al. (2007) found that Pinus pollen grains are transported from lowlands. The Pinus percentage is higher at Ledro (up to $80 \%$ ), so we assume that Pinus (pines) reached lake elevation.

Pollen grains from thermophilous and montane trees start to increase at ca. $14300 \mathrm{cal} \mathrm{BP}$. Considering that the age model is less robust for the pre-Holocene, this age is consistent with the temperature increase at the onset of the Allerød/Bølling interstadial (ca. $14600 \mathrm{cal} \mathrm{BP}$ ), which favoured an upward migration of the treeline in northern Italy (Tinner and Vescovi, 2005). Moreover, pollen grains from thermophilous and montane trees at Lake Ledro initially increased slowly, and then become more abundant at the end of this period. This trend may indicate gradual climate improvement, later reaching a maximum, as also shown in chironomid-inferred July air temperatures in the nearby Lago Lavarone (ca. 13 000-12 800 cal BP; Heiri et al., 2005).

\subsubsection{Impact of Younger Dryas cooling}

Climate deterioration in the Younger Dryas favoured a mixed open forest development (LL-4, Table 3). Heliophilous plants, such as Artemisia, developed with three maxima dated to ca. 12 400, 12100 and $11850 \mathrm{cal} \mathrm{BP}$. Other heliophilous plants, such as Pinus (pine) and Larix, seemed to be less favoured during these three phases; however, they reached their maximum when considering the entire YD. A similar pattern is recorded in the littoral core from Ponale (Magny et al., 2012). 
Table 3. Local pollen zones as established in Fig. $4 \mathrm{a}$ and $\mathrm{b}$ with indication of floristic composition, inferred vegetation change and correlation to biozones.

\begin{tabular}{|c|c|c|c|c|}
\hline $\begin{array}{l}\text { Lake } \\
\text { Ledro } \\
\text { LPAZ }\end{array}$ & $\begin{array}{l}\text { Age } \\
(\text { cal BP) }\end{array}$ & Event & Inferred vegetation change & $\begin{array}{l}\text { Correlation to } \\
\text { biozones }\end{array}$ \\
\hline LL-6d & 5300 & Abrupt $\nearrow$ Fagus & Dense oak-beech forest & Early Atlantic \\
\hline LL-6c & 6000 & $\nearrow$ Taxus & Mixed deciduous oak forest & Early Atlantic \\
\hline LL-6b & 7700 & $\nearrow$ Abies, first cereals & Montane trees development & Early Atlantic \\
\hline LL-6a & 9750 & $\nearrow$ Tilia, Fraxinus excelsior, Picea & Mixed deciduous oak forest & Early Atlantic \\
\hline LL-5b & 10350 & $\begin{array}{l}\searrow \text { Pinus, deciduous Quercus and } \\
\text { Ulmus abundant; abrupt } \nearrow \text { Corylus }\end{array}$ & $\begin{array}{l}\text { Mixed deciduous oak forest } \\
\text { development }\end{array}$ & Boreal \\
\hline LL-5a & 11700 & $\begin{array}{l}\text { Abrupt } \nearrow \text { deciduous Quercus, } \\
\text { Ulmus, Corylus; \Pinus and } \\
\text { Artemisia }\end{array}$ & Mixed deciduous oak forest & Preboreal \\
\hline LL-4 & 12700 & $\nearrow$ Artemisia and Pinus & Steppe tundra, open forest & Younger Dryas \\
\hline LL-3 & $\sim 14100$ & $\begin{array}{l}\nearrow \text { Betula and deciduous Quercus } \\
\text { then } \searrow \text { Betula; regular presence of } \\
\text { Corylus, Tilia, Alnus }\end{array}$ & $\begin{array}{l}\text { Afforestation: mixed open } \\
\text { forest }\end{array}$ & Allerød/Bølling \\
\hline LL-2 & $\sim 16500 ?$ & $\searrow$ Artemisia and Poaceae & Small afforestation & \\
\hline LL-1 & $\sim 17000 ?$ & $\nearrow$ Pinus and Poaceae & Pioneer/steppe tundra & Oldest Dryas \\
\hline
\end{tabular}

\subsubsection{Vegetation changes during the early Holocene (ca. 11 700-7700 cal BP)}

The beginning of the Holocene is characterised in the pollen record of Lake Ledro by a rapid expansion of mixed open broad-leaved forests in which Pinus (pines) are still abundant. More specifically, a mixed oak forest associated with Ulmus (elm) and Tilia (lime) develops at lake altitude. Such a concomitant population expansion was also described in the Lago di Lavarone record (Filippi et al., 2007).

Considering the Pinus (pine) reduction at the PreborealBoreal transition (ca. $10800 \mathrm{cal} \mathrm{BP}$ ), a similar decrease of this cold-adapted, heliophilous tree is observed at Lago di Lavarone (Filippi et al., 2007) and Lago di Fimon (23 m a.s.l., Valsecchi et al., 2008). Pinus (pine) is also linked with the light-demanding Corylus expansion at Lago di Fimon (Valsecchi et al., 2008), Lago di Origlio (Finsinger and Tinner, 2006) and Lago di Annone (Wick and Möhl, 2006). At higher elevations the decrease in the abundance of $\mathrm{Pi}$ nus (pine) occurred later, at ca. $9750 \mathrm{cal} \mathrm{BP}$, as in Totenmoos (Heiss et al., 2005).

\subsubsection{Vegetation changes during the middle Holocene (ca. 7700-3950 cal BP)}

The anthropogenic influence on the study area can be traced from cereal-type pollen grains and pollen-based vegetation that directly or indirectly resulted from anthropogenic activities. At Ledro, cereal-type pollen grains occurred sporadically from ca. $7500 \mathrm{cal}$ BP onwards. The low transportation potential of cereal-type pollen grains (Tweddle et al., 2005) suggests the establishment of Early Neolithic communities in the vicinity of the lake. However, other anthropogenic indicators are still sparse at that time. According to Bellini et al. (2008), agricultural activities began in Tuscany in the Neolithic (ca. $8000 \mathrm{cal} \mathrm{BP}$ ), and the openness of the landscape could also be a consequence of anthropogenic clearing practices. In northern Italy, Rottoli and Castiglioni (2009) reported the appearance of farming communities at ca. 7600$7500 \mathrm{cal}$ BP. According to these authors, Early Neolithic agriculture spread rapidly (over a few centuries) throughout the Alps, which is in accord with the pollen record of Lake Ledro.

Picea and Abies proportion declined concomitantly with a significant increase in Corylus at ca. 6700 and ca. $6000 \mathrm{calBP}$. These short-term vegetation replacements thus complete the relationship described in Sect. 5.2.4 (Picea development) as it illustrates the light-demanding Corylus benefitting from Picea (spruce) and Abies regression. Peaks of cereal-type pollen grains just precede these vegetation changes by approximately $100 \mathrm{yr}$ and around $50 \mathrm{yr}$ at ca. 6800 and ca. $6050 \mathrm{cal} \mathrm{BP}$, respectively. However, the abruptness and brevity of these changes may suggest catastrophic events, such as fire, which may also be triggered by humans. Picea and Abies redeveloped afterwards, associated with the appearance of Taxus in the pollen diagram.

The Taxus amount increase was reported previously by Beug (1964). The age-depth model indicates an age of ca. $5500 \mathrm{cal}$ BP for this tree development, which occurred at the onset of the second increase of Fagus. Taxus is not present in the record from Lago di Lavarone (Filippi et al., 2007), but 


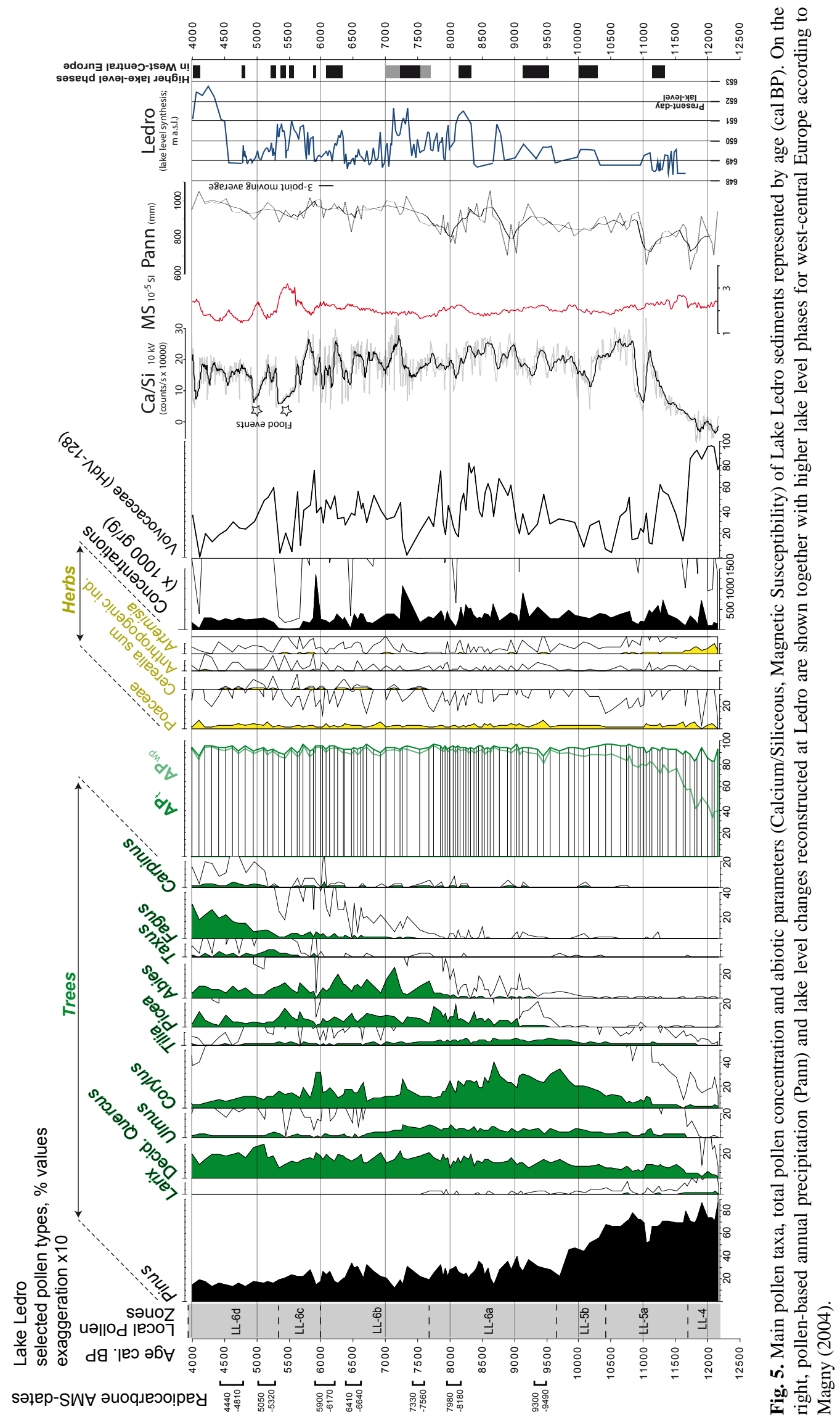


exists at Lago di Annone (Wick and Möhl, 2006) and Lago della Costa (ca. 6000 cal BP; Kaltenrieder et al., 2010).

\subsection{Immigration and development of key taxa in the southern Alps}

\subsubsection{Abies immigration}

To discuss the persistence and spread of Abies, pollen diagrams from the southern Alps were compiled in Fig. 6. These records generally show that Abies pollen grains are first recorded continuously with low percentages (below 1\%) for millennia before Abies development marked by higher percentages. Furthermore, pollen productivity and the transport potential of Abies are low (Huntley and Birks, 1983). For these two reasons, low and continuous percentages can therefore be interpreted as significant. This characteristic is confirmed by Van der Knaap et al. (2005), who indicated that the assumed pollen-percentage thresholds (between 0.5 and $8 \%$ ) are similarly robust when studying spatial patterns (latitude, longitude and elevation) in migration and/or population expansion.

At the lowland Lago della Costa site (7 ma.s.l.; Kaltenrieder et al., 2009, 2010), Abies is continuously recorded from last Glacial. The first continuous record of Abies pollen grains is dated to ca. $15500 \mathrm{cal} \mathrm{BP}$ in Lago Piccolo di Avigliana (353 m a.s.l.; Finsinger et al., 2006), ca. $13000 \mathrm{cal} \mathrm{BP}$ in Balladrum ( $390 \mathrm{~m}$ a.s.l.; Hofstetter et al., 2006), ca. 12800 cal BP in Lago di Origlio (416 m a.s.l.; Tinner et al., 1999), ca. $12800 \mathrm{cal} \mathrm{BP}$ in Lake Ledro, ca. $11800 \mathrm{cal} \mathrm{BP}$ in Lago di Lavarone (1100 m a.s.l.; Filippi et al., 2007), ca. $11000 \mathrm{cal}$ BP in Pian di Gembro (1350 m a.s.l.; Pini, 2002) and in Piano (1439 ma.s.l.; Valsecchi and Tinner, 2010), ca. 10800 cal BP in Palughetto (presence of stomata; $1040 \mathrm{~m}$ a.s.l.; Vescovi et al., 2007), ca. $9100 \mathrm{cal} \mathrm{BP}$ in Totenmoos (1718 ma.s.l.; Heiss et al., 2005) and at ca. $8500 \mathrm{calBP}$ in Lej da San Murezzan (1768 m a.s.l.; Gobet et al., 2003). These estimated ages of the first continuous records of Abies pollen grains (sometimes including Abies stomata) have been plotted according to the elevation of the sites on Fig. 6a. This shows a progressive delay with increasing altitude and a trend that was quantified using linear regression $(r=-0.93 ; p<0.001)$, of approximately $225 \mathrm{~m} / 1000 \mathrm{yr}$ in the southern Alps.

The Abies pollen record of Lago del Greppo (1442 m a.s.l.; Vescovi et al., 2010) in the northern Apennines is clearly excluded and therefore suggests a distinct pattern for the Abies spread in this area. Altitudinal abundance reflects the ecological optimum of trees so that tree migration was faster at optimum elevation and slower at lower and higher elevations, rather than exhibiting a linear relationship with elevation (van der Knaap et al., 2005). This observation explains why Abies migration in the southern and northern Alps shows an inadequate linear regression with elevation (van der Knaap et al., 2005), as indicated by the scarcity of $p$ values.
Discrepancies with results from our study is therefore expected to be due to location and number of sites (southernnorthern Alps and 68 sites in van der Knaap et al.; southern Alps and 11 sites in our study) as other authors observed a clear relationship between Abies migration and latitude (a northward migration).

This trend suggests that altitudinal conditions drove the spread of Abies trees in the southern Alps, despite non-linear climate improvement and glacier retreat since the Lateglacial and various topographical, edaphical and microclimatical conditions. However, low percentages indicate that Abies did not form Abies forests. This trend may also question whether Abies formed refugial populations in the lowlands (senso stricto) or hilly areas (Kaltenrieder et al., 2009). This study provides helpful data and insights from Lago della Costa, situated at the edge of the Euganean Hills (up to $800 \mathrm{~m}$ ), where favourable microenvironmental conditions may have occurred. However, Abies refugia cannot be excluded in the case of lowlands, which were at higher elevation when considering a lower sea level. Hofstetter et al. (2006) discussed the possible persistence of Abies at high altitudes during the Lateglacial on the southern slope of the Alps by excluding (but not completely) long-distance transport from the Apennines. However, the persistence of Abies at high altitudes is not corroborated by the present study.

\subsubsection{Larix immigration and its development}

Larix pollen grains reflect the Larix development at a relatively low altitude during the Lateglacial (Lago della Costa, Kaltenrieder et al., 2009; Lago Ragogna, Monegato et al., 2007; Lago Piccolo di Avigliana, Finsinger et al., 2006). Larix development is delayed according to elevation in the southern Alps (Fig. 6b) and is reported from $800-900 \mathrm{~m}$ at the onset of the Allerød/Bølling interstadial (Vescovi et al., 2010) and between 1000 and $1700 \mathrm{~m}$ (Lago di Lavarone, Filippi et al., 2007; Pian di Gembro, Pini, 2002; Palughetto, Vescovi et al., 2007; Totenmoos, Heiss et al., 2005) during the Allerød/Bølling interstadial. However, the Lake Ledro pollen record differs, as Larix development occurred at lower altitude during this period. Thus, this trend needs to be confirmed, particularly for the interval between ca. 16500 $14500 \mathrm{cal} \mathrm{BP}$.

From ca. 14 000-12 500 and ca. 11 500-9500 cal BP, Larix is found in high abundance at Totenmoos in north-eastern Italy (1718 m a.s.l.; Heiss et al., 2005). During the YD, Larix amounts reached their maximum at neighbouring Palughetto (1040 ma.s.l.; Vescovi et al., 2007) and Pian di Gembro (1350 m a.s.l.; Pini, 2002). Thus, low Larix abundance at Totenmoos suggests that the treeline was at lower altitude (i.e. between 1350 and $1718 \mathrm{~m}$ ). This elevational pattern confirms that the treeline was above $1400 \mathrm{~m}$ in the southern Alps, as suggested by Vescovi et al. (2007), and agrees with a treeline located at ca. $1500 \mathrm{~m}$ a.s.l., as suggested by Gobet et al. (2005). At Ledro, Larix developed from 14000 to 
7500 cal BP and simultaneously disappeared from the nearby Lago di Lavarone (1100 m a.s.l.; Filippi et al., 2007). However, taxonomic identification of macrocharcoal fragments suggest that Larix presence is continuously recorded during Holocene times at a higher altitude in the nearby Valle di Sol (up to $2200 \mathrm{~m}$ a.s.1.; Trentino, Favilli et al., 2010). Larix presence has also been documented for the last millennia in Lake Tovel (1177 m a.s.l.; Gottardini et al., 2004). This discrepancy may result from varying situations of the Larix developments in alpine valleys or, more likely, to a bias in the pollen record because Larix has poor pollen distribution (Sjögren et al., 2008). A large part (25\%) of the Bronze Age lakedwelling wood piles found in Lake Ledro littoral are Larix wood (Pinton and Carrara, 2007), and Larix woodland occurs today in the subalpine belt of the Ledro valley (Magny et al., 2009). The absence of Larix grains in the pollen diagram since ca. $7500 \mathrm{cal} \mathrm{BP}$ is thus a distribution artefact, which also argues for a lower-than-today elevation of the treeline by the time of Larix records in the lake.

\subsubsection{Corylus development}

Corylus developed later than deciduous Quercus (LL-5a), as it is generally observed in the southern Alps (Finsinger et al., 2006) at Lago Piccolo di Avigliana (353 m a.s.l.) and Lago di Origlio. Thus, this pattern is the opposite that of the northern Alps, where Corylus expanded before deciduous Quercus. In more detail, the age for Corylus expansion given at Lago Piccolo di Avigliana and Lago di Origlio (between ca. 10400 and ca. $10200 \mathrm{cal} \mathrm{BP}$; Finsinger et al., 2006) does not correspond to the first Corylus increase at Lake Ledro (ca. $11200 \mathrm{cal} \mathrm{BP}$ ), nor to the second increase at ca. $10750 \mathrm{cal}$ BP. At Ledro, Corylus expansion is complicated by the fact that the first and second expansions are separated by a 300-yr-long decline (from ca. 11100 to ca. 10800 cal BP), which also affected deciduous Quercus, Ulmus and Tilia. This event temporarily affected most of the temperate trees, suggesting that the first increase of Corylus has to be considered to integrate the discussion about Corylus expansion in Europe (Fig. 6c). Corylus expansion, therefore, seems to be older than that observed at Lago di Annone (226 m a.s.l.; Wick and Möhl, 2006) and more in accordance with Lago di Fimon (Valsecchi et al., 2008). However, when looking at other pollen records from the southern and northern Alps, and considering the reliability of age estimates, Corylus expansion occurred in a short interval between 11200 and $10100 \mathrm{cal} \mathrm{BP}$ (Fig. 6c). This corroborates the conclusions of Finsinger et al. (2006), who reported a broadly synchronic Corylus expansion in the northern and southern Alps, as well as those of Giesecke et al. (2011), who observed a synchronic rise in Corylus in central and northern Europe.

\subsubsection{Picea development}

The rare presence of Picea pollen in the Lake Ledro sediments, estimated to have occurred in glacial times, is most likely due to wind dispersal. Van der Knaap et al. (2005) assumed that a low pollen level indicates the approximate immigration time and the beginning of population expansion. Picea development is dated to ca. $9100 \mathrm{cal} \mathrm{BP}$ in Lake Ledro (Fig. 6d). This is more recent than records from Palughetto (1040 ma.s.l.; Vescovi et al., 2007) and Lago Ragogna (188 m a.s.l.; Monegato et al., 2007), which show Picea development during the Allerød/Bølling interstadial. The age for Lake Ledro Picea development is more similar to those from Lago di Lavarone (Filippi et al., 2007), Lago del Greppo (Vescovi et al., 2010), Totenmoos (Heiss et al., 2005) and Passo del Tonale (1883 m a.s.l.; Gehrig, 1997). This age is older than Pian di Gembro (1350 m a.s.l.; Pini, 2002), Lej da San Murezzan (Gobet et al., 2003) and Palù di Sonico (650 m a.s.l., Gehrig, 1997). Thus, no clear relationship between altitude and Picea development is observed in the southern Alps and a westward development is more apparent. At the scale of the southern and northern Alps, this pattern was observed by Ravazzi (2002) and shown statistically by van der Knaap et al. (2005).

Pini (2002) discussed increasing humidity in the early Holocene, which favoured the development of Picea and Abies to form montane coniferous forests. According to Pini (2002), Picea moved down from higher altitudes to colonise montane altitudes. The same observation was reported by van der Knaap et al. (2005) based on pollen records from the southern and northern Alps. In the present study, considering only the southern Alps, we suggest that Picea expansion was unrelated to altitude, and factors other than climate are expected to be important. Corylus and Picea are anti-correlated $(r=-0.58 ; p<0.001)$ in the interval 9750$7700 \mathrm{cal}$ BP. This relationship is also established in Norway (Seppä et al., 2009), where the dominance of Picea abies was caused by its rapid population growth, competitive suppression of other taxa (particularly Corylus and Tilia), and local edaphic factors. We can thus postulate that both climate and competitive capacity may have triggered Picea development at Ledro.

\subsubsection{Fagus development}

Focusing on Fagus (beech), we found a bi-phased expansion from ca. 7500 to ca. $6000 \mathrm{cal} \mathrm{BP}$, and from ca. 5300 to ca. $4050 \mathrm{cal}$ BP. A bi-phased expansion is also observed at Lago di Fimon (Valsecchi et al., 2008) with similar ages for the onset of these phases, while ages for maximal content are not comparable. Valsecchi et al. (2008) discussed the relationship between Fagus establishment and climate vs. anthropogenic factors. They used cross-spectral analysis on pollen and charcoal to conclude that no single factor was determinant. Anthropogenic indicators, such as Rumex and 


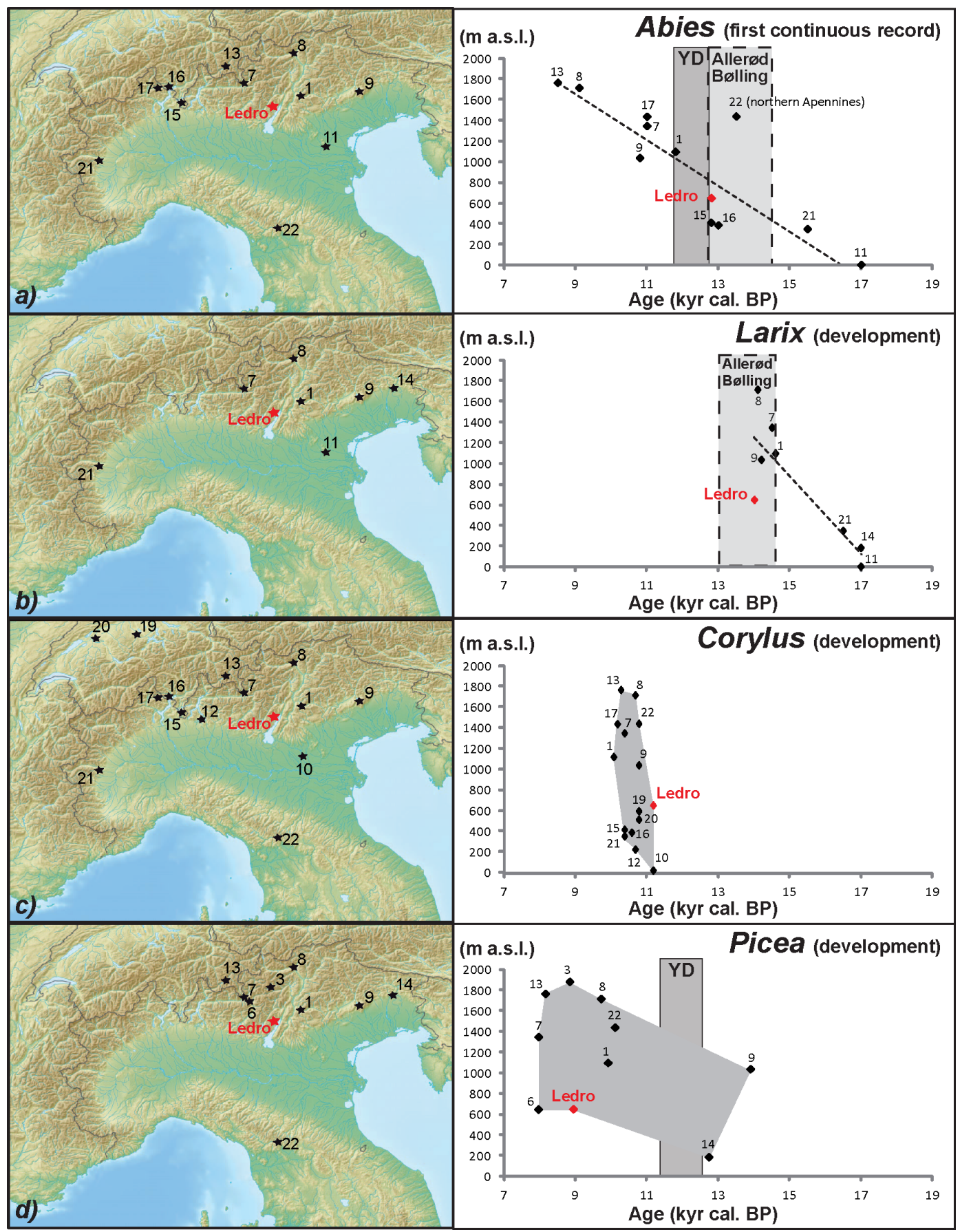

Fig. 6. Compilation of pollen records (plus macrofossil and stomata data when available) from the southern Alps and Switzerland and the northern Apennines. Location of sites and graphs are provided, where age estimates are plotted against altitude, for the four tree taxa Abies, Larix, Corylus and Picea. Site numbers refer to the caption from Fig. 1. (a) Ages of the first continuous Abies (fir) record; (b), (c) and (d) ages for the development of Larix (larch), Corylus (hazel) and Picea (spruce). YD = Younger Dryas.

Plantago lanceolata, are observed continuously in the pollen record of Lake Ledro since the Lateglacial. Thus, it appears to be preferable, in the present discussion of Fagus establishment, to focus on cereal-type pollen grains, which occurred sporadically during the bi-phased Fagus development.
These occurrences are out of phase with Fagus variations and therefore suggest that Fagus development was most likely not related to human activities. Lago di Lavaronne, at higher altitude (i.e. $1100 \mathrm{~m}$ a.s.l.; Filippi et al., 2007), had a onephase increase in Fagus at ca. $8000 \mathrm{cal} \mathrm{BP}$. The Lake Ledro 
catchment area provides pollen grains from higher altitudinal vegetation belts, so it is remarkable that the rise in $\mathrm{Fa}$ gus differs both in age and pattern. This difference raises the question whether a common factor (i.e. human impact) could explain different Fagus development patterns from areas in close proximity. At Ledro, the existence of agriculture is confirmed by pollen analysis, while pastoral activity in the catchment area is not. Raw data thus indicate a minor anthropogenic influence, but we cannot clearly assess the anthropogenic role for influencing the bi-phased Fagus development.

\subsection{Climate and human influences on vegetation in north-eastern Italy}

\subsubsection{Beginning of the early Holocene (before ca. 11000 cal BP)}

Before ca. 11200 cal BP (Fig. 5), Ca/Si values indicate the onset of less erosive activity, which is correlated with the pollen-based vegetation history showing rapid afforestation. Warmer, wetter climate conditions (shown by increasing pollen-based annual precipitation values; Fig. 5; Peyron et al., this volume) associated with the final stages of deglaciation, triggered forest expansion, which in turn limited erosional processes (Olsen et al., 2010) and Si delivery to the lake. Volvocaceae decreased during this phase of environmental change. This algae family is typical for an open, less deep lake (Jouffroy-Bapicot, 2010), and its decrease in abundance may indicate rising lake levels and more mesotrophic conditions in the lake.

A centennial-scale drop in percentages of deciduous Quercus, Ulmus and Corylus is recorded at ca. $11100 \mathrm{cal} \mathrm{BP}$. This period corresponds to lower pollen-based annual precipitation and temperature estimates for the coldest month (Peyron et al., 2012) and to a deposit characterised by low $\mathrm{Ca} / \mathrm{Si}$ values. Simultaneously, small and short successive rises and drops are recorded in the littoral section from Ponale (Fig. 5; Magny et al., 2012), suggesting cooler and drier conditions. The timing and duration of these events recorded in both biotic and abiotic proxies can be interpreted as the cold Preboreal oscillation, which temporarily recalls less favourable climate conditions than during YD. Palaeoenvironmental records obtained using stable isotopes from the Swiss Plateau revealed a Preboreal oscillation (PBO), but no significant effect on low-altitude vegetation (Gerzensee, $602 \mathrm{~m}$ a.s.l., Lotter et al., 2000). The pollen-based vegetation response is strongly recorded in the catchment of Lake Ledro as it is generally more pronounced near vegetation ecotones at medium and higher altitudes than in lowlands (Wick, 2000). A cold oscillation has also been observed for the Preboreal chronozone in the pollen stratigraphy of Lago di Avigliana (Finsinger and Tinner, 2006). A cooling and drought event is also evidenced in pollen and lake level records from Lago di Accesa (Magny et al., 2006a; Finsinger et al., 2010) and linked with the PBO. Magny et al. (2007) provided a lake level synthesis for the PBO (ca. 11 300-11 150 cal BP, as defined from the GRIP oxygen isotope record) and concluded that wetter climatic conditions prevailed in west-central Europe, while a marked climatic drought characterised northcentral Italy. A growing body of studies extends the occurrence of this dry phase toward southern Italy (e.g. Joannin et al., 2012; Di Rita et al., 2013). Lake Ledro pollen and sedimentological records are therefore in the line with a cooling and drying climate during the PBO for all of Italy.

\subsubsection{Early-middle Holocene (ca. 11 000-5700 cal BP)}

From ca. 10800 to 5700 cal BP, the forest cover, which was inferred from AP percentages, stabilised at approximately 90-95\%, and geochemical measurements show a high $\mathrm{Ca} / \mathrm{Si}$ ratio. Again, biotic and abiotic proxies indicate that climate conditions in the Lake Ledro catchment enhanced forest cover large enough to limit run-off and erosion activity, though successive taxa replacement occurred with reduction of temperate trees and the expansion of montane trees. Increasing pollen-based annual precipitation values, which have been $>800 \mathrm{~mm} \mathrm{yr}^{-1}$ since ca. $10800 \mathrm{cal} \mathrm{BP}$, are triggered mainly by increasing summer precipitation (Peyron et al., 2012) associated with lower temperature in the warmest month. Lake level variations and flood frequency are in general low during this phase (Magny et al., 2012; Vannière et al., 2012). Thus, vegetation and sediment records, on a multimillennial scale, show generally stable climate conditions from ca. 10800 to 5700 cal BP.

However, the present study shows a more complex history along this interval. A peak in the $\mathrm{Ca} / \mathrm{Si}$ ratio is recorded at ca. $10200 \mathrm{cal} \mathrm{BP}$ and correlates with an increase of lightdemanding Corylus and Fraxinus excelsior. This feature coincides with the cooling during the oldest Boreal oscillation (Magny et al., 2007). Another change started from ca. $9300 \mathrm{cal}$ BP onwards, as montane trees clearly expanded (mainly Abies and Picea). The well-known Boreal oscillations (9300-9050 and $8750 \mathrm{cal} \mathrm{BP}$; Magny et al., 2007) and the $8.2 \mathrm{kyr}$ cold event coincided with Picea and Abies expansion, respectively. These events are marked by $\mathrm{Ca} / \mathrm{Si}$ drops, which indicate increasing run-off and are associated with rises in lake level (Fig. 5; Magny et al., 2012), decreases in annual precipitation (mostly forced by winter precipitation changes) and decreases in temperature of the coldest month (Peyron et al., this volume). These cold and dry events occurred within the 9000-8000 cal BP interval, which is interpreted as a partial return to cooler conditions following an orbitally driven delay in Northern Hemisphere deglaciation (Mayewski et al., 2004). Finally, montane coniferous forests may record the vegetation response to the long-lasting cumulative effect of these decadal-centennial successive events. Accordingly, Picea development in the south-eastern Alps preferentially occurred at approximately 10000 and $8200 \mathrm{cal} \mathrm{BP}$ (Fig. 6d). 
After ca. 8200 cal BP, Abies develops in the Lake Ledro catchment as well as in Pian di Gembro (Pini, 2002). This tree is meso-hygrophile, and its development, which requires a minimum precipitation of $800 \mathrm{~mm} \mathrm{yr}^{-1}$ without long summer dryness, has also been shown important from ca. 8200 to 7200 cal BP in Lago di Annone (Wick and Möhl, 2006). During this interval, a general increase in lake level is observed in Lake Ledro, where higher lake levels are coeval (and may trigger) with the low development of Volvocaceae at ca. 8200 and $7500-7300 \mathrm{cal} \mathrm{BP}$ (Fig. 5). A general increase in the pollen-based reconstruction of annual precipitation is observed between ca. $8500-8200$ and 7300$7100 \mathrm{cal}$ BP. This increase is mostly triggered by increased summer precipitation during the first half of this interval (Peyron et al., 2012). Based on spring to autumn floods, Vannière et al. (2012) observed an increase in flood activity from ca. 8000-7000 cal BP. Taken together, and considering dating uncertainties, these observations corroborate the wet climate scenario for the Alps recognised in the Corchia's speleothem (Spötl et al., 2010). Based on reconstructed $\delta^{18} \mathrm{O}$ (Zanchetta et al., 2007) and dendrochronological data provided by the East Alpine Conifer Chronology (Nicolossi et al., 2009), these authors observed rainy summers from ca. 8200 to $7300 \mathrm{cal} \mathrm{BP}$. According to Pini (2002), expansion of Abies at middle and high altitudes started from the lowlands at ca. $11500 \mathrm{cal} \mathrm{BP}$ and benefitted from increasing humidity at ca. $8200 \mathrm{cal} \mathrm{BP}$. Pini (2002) questioned the direct relationship between sudden Picea and Abies expansion with climate change. Our study indicates that Picea development is more likely influenced by several factors, such as the long-lasting, cumulative effects of decadal-centennial, successive climate events, which occurred from ca. 10200 to 8200 cal BP, and competitive capacity.

Large changes in Abies are noteworthy from ca. 7600$6700 \mathrm{cal} \mathrm{BP}$, which, within dating uncertainty, is not comparable to abrupt collapses of Abies during Misox events that developed at high-elevation sites in the southern Alps (Piano; Valsecchi and Tinner, 2010). At ca. $5700 \mathrm{cal} \mathrm{BP}$, the cerealtype sum suggests human occupation along the lakeshore. No relationship is observed between pollen-based human activities (i.e. crops), vegetation changes in the landscape (such as forest clearance), changes in pollen concentrations, and geochemical variations up to ca. $5700 \mathrm{yr}$ cal BP, so we conclude that climate was the dominant factor controlling vegetation changes during a phase of low human impact.

\subsubsection{Final middle Holocene (ca. 5700-4100 cal BP)}

From ca. 5700 to ca. $4100 \mathrm{cal} \mathrm{BP}$, more contrasted values in abiotic records are observed. Vegetation is still largely forested, but includes more anthropogenic indicators (mainly representing farming). As discussed above, vegetation and Fagus developments are largely climatically controlled. Abiotic indicators show clear and strong changes, which leads us to separate this phase from the previous one. As the anthropogenic influence is low, two very thick and exceptional deposits recorded ca. 5800-5300 cal BP (Vannière et al., 2012) may indicate major climate instabilities, which most likely enhanced erosion in the catchment. Magny (2004) and Magny et al. (2012) have discussed the possible impact of wetter and cooler events between ca. 6000 and ca. $5000 \mathrm{cal}$ BP in Europe, possibly related to rapid climate changes (RCC) suggested by Mayewski et al. (2004). Local expression of these RCC may thus have affected the precipitation regime in this part of the Alps and caused successive lake level rises and stopped Fagus development between ca. 5800 and ca. 5300 cal BP in the Ledro. This phenomenon may be linked with successive episodes of higher lake level between ca. 5550 and ca. 5300 cal yr BP at Lake Constance, coinciding with glacier advances (Magny and Haas, 2004) during the Neoglacial (Zanchetta et al., 2012).

At ca. 4500 cal BP, the lake level showed an abrupt rise that continued onwards with a high average water table (Magny et al., 2012). Again, low development of Volvocaceae appears to be related to deeper water depth. According to Vannière et al. (2012), flood activity has increased since ca. $4500 \mathrm{cal}$ BP onwards, suggesting a major change in the palaeohydrological regime. These authors also report that the rupture reflects a non-linear climate response to the orbitally driven gradual decrease in summer insolation (Zhao et al., 2010), which caused the millennial trend toward wet conditions during the late Holocene. Lake level rises therefore suggest higher humidity during summer (Magny et al., 2012), while both pollen-based summer and winter precipitation increased (Peyron et al., this volume). Valsecchi et al. (2008) report tree-ring studies, which evidence a reduced Fagus growth (at its southern range) in response to dry summers (Jump et al., 2006). We observe that the Fagus forest development in the Ledro pollen record was (1) stopped between ca. 6000 and ca. 5300 cal BP during wet, cooler summers (based on the pollen-based temperature of the warmest month; Peyron et al., 2012), and (2) was strong thereafter due to wetter and warmer summers. As for Lago di Fimon, we can conclude that low Fagus population densities since ca. $7500 \mathrm{cal}$ BP indicate that population expansion was not favoured by the previous cold and wet phases (Valsecchi et al., 2008). However, in the context of minor anthropogenic influence in Ledro, $\mathrm{Fa}$ gus expansion may have benefitted from wetter summers.

\section{Conclusions}

We investigated pollen-based vegetation changes recorded in the sediments of Lake Ledro (652 ma.s.l.) since the Lateglacial, particularly for the last $12000 \mathrm{yr}$. By comparing the continuous and high-resolution pollen records with those from other sites in the southern and northern Alps, we were able to discuss successive increases in taxa abundances. We considered their climatical and ecological requirements relative to their expansion in the southern Alps from various 
glacial refuges. A progressive, altitudinal time delay for the first continuous occurrence of Abies was observed since the Lateglacial in the southern Alps. This tree expanded as single trees from the lowlands (or hilly areas) long before the development of dense Abies forests. Larix development also is delayed according to altitude, though this trend is not sufficiently documented. This pattern confirms that the treeline was above $1400 \mathrm{~m}$ in the southern Alps during the Younger Dryas. Thus, it appears that despite its mid-altitude position, the Ledro catchment cannot be considered a refugial for Abies, Larix and Picea. This conclusion suggests that trees originate from lowlands (e.g. Euganean Hills) and, with the upward migration of the treeline, colonised the area during the climate improvement in the early Holocene. Corylus and Picea developments, which occurred at 11200-10 100 and between 14500 and 8200 cal BP, respectively, do not show a delay according to altitude. The broadly synchronic Corylus expansion in the Alps is a common feature recognised in central and northern Europe. The expansion pattern of Picea is more surprising and occurred ca. 10200 and $8200 \mathrm{cal} \mathrm{BP}$ in the south-eastern Alps, and therefore reflected the longlasting cumulative effects of successive Boreal and $8.2 \mathrm{kyr}$ cold events.

Pollen analysis and pollen-based climate reconstructions were coupled with lake level variations and abiotic proxies, such as magnetic susceptibility and elemental variation from the Lake Ledro long core, to reveal the local impacts of climate change and land-use activities. On a millennial scale, climate is the dominant factor controlling vegetation and erosional processes during the early and middle Holocene (up to $4100 \mathrm{cal}$ BP). Accordingly, a steady climate change toward wetter conditions allowed deciduous Quercus, Corylus, Picea, Abies, Fagus and Taxus (yew) to successively expand and regress. Human impact, recorded since $7500 \mathrm{cal} \mathrm{BP}$, is low. Sporadic occurrences of cereal-type pollen grains are out of phase with the observed bi-phased Fagus variations, suggesting that Fagus development is not related to human activities in the Ledro area and may have benefitted from wetter summers. No important pastoral activity is observed during periods of declining Taxus abundance, which is more likely caused by a concomitant change to dense forest, mostly dominated by the shade-giving Fagus. A shift toward colder and wetter conditions (mostly during summers) is recognised from 5700 to $4100 \mathrm{cal} \mathrm{BP}$ (i.e. during the Neoglacial period), yet human influence remained low.

On a centennial scale, the Preboreal $(11000 \mathrm{cal} \mathrm{BP})$ and Boreal oscillations (10 200, 9300-9050 and $8750 \mathrm{cal} \mathrm{BP}$ ) are evidenced in biotic and abiotic records. They thus correspond to cold and/or dry climate installation, and forced shortterm vegetation changes. The interval $9000-8000 \mathrm{cal} \mathrm{BP}$ is a cold and dry interval, which is interpreted as a partial return to cooler conditions following an orbitally driven delay in the Northern Hemisphere deglaciation. Expansion of Abies is contemporaneous with the $8.2 \mathrm{kyr}$ cold event, but its development in the southern Alps benefitted from the wettest interval, 8200-7300 cal BP, as evidenced in lake levels, flood activity and pollen-based climate reconstruction.

Acknowledgements. Financial support for this study was provided by the French ANR (project LAMA, M. Magny and N. Combourieu Nebout) as well as by the Ecole Française de Rome. We thank W. Fletcher, one anonymous reviewer and N. Combourieu Nebout (Editor) for thorough reviews and appreciable improvements of this manuscript. The authors are thankful to Jacques-Louis de Beaulieu for his review on a previous version of the manuscript. We are grateful to Julien Didier for his help in the laboratory, and David Etienne, Laurent Millet and Damien Rius for their help with data processing.

Edited by: N. Combourieu Nebout

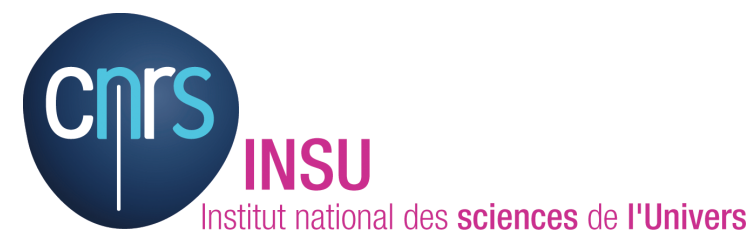

The publication of this article is financed by CNRS-INSU.

\section{References}

Bellini, C., Mariotti-Lippi, M., Mori Secci, M., Aranguren, B., and Perazzi, P.: Plant gathering and cultivation in prehistoric Tuscany (Italy), Veg. Hist. Archaeobot., 17, 103-112, 2008.

Beug, H. J.: Untersuchungen zur spätglazialen Vegetationsgeschichte im Gardaseegebiet unter besonderer Berücksichtigung der mediterranen Arten, Flora, 154, 401444, 1964.

Beug, H. J.: Leitfaden der Pollenbestimmung für Mitteleuropa und angrenzende Gebiete, Friedrich Pfeil, München, 2004.

Björck, S., Rundgren, M., Ingolfsson, O., and Funder, S.: The Preboreal oscillation around the Nordic Seas: terrestrial and lacustrine responses, J. Quaternary Sci., 12, 455-465, 1997.

Björck, S., Muscheler, R., Kromer, B., Andresen, C.S., Heinemeier, J., Johnsen, S.J., Conley, D., Koç, N., Spurk, M., and Veski, S.: High-resolution analyses of an early Holocene climate event may imply decreased solar forcing as an important climate trigger, Geology, 29, 1107-1110, 2001.

Blaauw, M.: Methods and code for "classical" age-modelling of radiocarbon sequences, Quat. Geochronol., 5, 512-518, 2010.

Combourieu-Nebout, N., Dormoy, I., Sadori, L., Peyron, O. and Joannin, S.: Central Mediterranean vegetation and climate changes from Holocene pollen records in the Adriatic Sea area, Clim. Past, in preparation, 2013.

Cruise, G. M., Macphail, R. I., Linderholm, J., Maggi, R., and Marshall, P. D.: Lago di Bargone, Liguria, N Italy: a reconstruction of Holocene environmental and land-use history, Holocene, 19, 987-1003, 2009.

Davis, B. A. S. and Brewer, S.: Orbital forcing and role of the latitudinal insolation/temperature gradient, Clim. Dynam., 32, 143165, 2009. 
Dearing, J. A., Hay, K. L., Baban, S. M. J., Huddleston, A. S., Wellington, E. M. H., and Loveland, P. J.: Magnetic susceptibility of soil: An evaluation of conflicting theories using a national data set, Geophys. J. Int., 127, 728-734, 1996.

Di Rita, F., Anzidei, A. P., and Magri, D.: A Lateglacial and early Holocene pollen record from Valle di Castiglione (Rome): vegetation dynamics and climate implications, Quatern. Int., 288, 73-80, 2013.

Dormoy, I., Peyron, O., Combourieu Nebout, N., Goring, S., Kotthoff, U., Magny, M., and Pross, J.: Terrestrial climate variability and seasonality changes in the Mediterranean region between 15000 and 4000 years BP deduced from marine pollen records, Clim. Past, 5, 615-632, doi:10.5194/cp-5-615-2009, 2009.

Drescher-Schneider, R., de Beaulieu, J., Magny, M., WalterSimonnet, A., Bossuet, G., Millet, L., Brugiapaglia, E., and Drescher, A.: Vegetation history, climate and human impact over the last 15,000 years at Lago dell'Accesa (Tuscany, Central Italy), Veg. Hist. Archaeobot., 16, 279-299, 2007.

Favilli, F., Cherubini, P., Collenberg, M., Egli, M., Sartori, G., Schoch, W., and Haeberli, W.: Charcoal fragments of Alpine soils as an indicator of landscape evolution during the Holocene in Val di Sole (Trentino, Italy), Holocene, 20, 67-79, 2010.

Filippi, M. L., Heiri, O., Arpenti, E., Angeli, N., Bortolotti, M., Lotter, A. F., and Van Der Borg, K.: Evoluzione paleoambientale dal Tardoglaciale a oggi ricostruita attraverso lo studio dei sedimenti del Lago di Lavarone (Altopiano di Folgaria e Lavarone, Trentino), Studi Trent. Sci. Nat. Acta Geol., 82, 279-298, 2007.

Finsinger, W. and Tinner, W.: Holocene vegetation and land-use changes in response to climatic changes in the forelands of the southwestern Alps, Italy, J. Quaternary Sci., 21, 243-258, 2006.

Finsinger, W., Tinner, W., van der Knaap, W. O., and Ammann, B.: The expansion of hazel (Corylus avellana L.) in the southern Alps: a key for understanding its early Holocene history in Europe?, Quaternary Sci. Rev., 25, 612-631, 2006.

Finsinger, W., Colombaroli, D., De Beaulieu, J., Valsecchi, V., Vannière, B., Vescovi, E., Chapron, E., Lotter, A. F., Magny, M., and Tinner, W.: Early to mid-Holocene climate change at Lago dell'Accesa (central Italy): climate signal or anthropogenic bias?, J. Quaternary Sci., 25, 1239-1247, 2010.

Fleitmann, D., Burns, S. J., Mangini, A., Mudelsee, M., Kramers, J., Villa, I., Neff, U., Al-Subbary, A. A., Buettner, A., Hippler, D., and Matter, A.: Holocene ITCZ and Indian monsoon dynamics recorded in stalagmites from Oman and Yemen (Socotra), Quaternary Sci. Rev., 26, 170-188, 2007.

Fletcher, W. J., Sanchez Goñi, M. F., Peyron, O., and Dormoy, I.: Abrupt climate changes of the last deglaciation detected in a Western Mediterranean forest record, Clim. Past, 6, 245-264, doi:10.5194/cp-6-245-2010, 2010.

Gedye, S. J., Jones, R. T., Tinner, W., Ammann, B., and Oldfield, F.: The use of mineral magnetism in the reconstruction of fire history: a case study from Lago di Origlio, Swiss Alps, Palaeogeogr. Palaeocl., 164, 101-110, 2000.

Gehrig, R.: Pollenanalytische Untersuchungen zur Vegetations- und Klimageschichte des Val Camonica (Norditalien), J. Cramer, Berlin, Stuttgart, 1997.

Giesecke, T., Bennett, K. D., Birks, H. J. B., Bjune, A. E., Bozilova, E., Feurdean, A., Finsinger, W., Froyd, C., Pokorny, P., Roesch, M., Seppa, H., Tonkov, S., Valsecchi, V., and Wolters, S.: The pace of Holocene vegetation change - testing for synchronous developments, Quaternary Sci. Rev., 30, 2805-2814, 2011.

Giraudi, C., Magny, M., Zanchetta, G., and Drysdale, R. N.: The Holocene climatic evolution of Mediterranean Italy: A review of the continental geological data, Holocene, 21, 105-115, 2011.

Gobet, E., Tinner, W., Hochuli, P., van Leeuwen, J., and Ammann, B.: Middle to Late Holocene vegetation history of the Upper Engadine (Swiss Alps): the role of man and fire, Veg. Hist. Archaeobot., 12, 143-163, 2003.

Gobet, E., Tinner, W., Bigler, C., Hochuli, P. A., and Ammann, B.: Early-Holocene afforestation processes in the lower subalpine belt of the Central Swiss Alps as inferred from macrofossil and pollen records, Holocene, 15, 672-686, 2005.

Gottardini, E., Cristofori, A., Cristofori, F., and Oeffl, K.: Palynological analyses on sediments of Lake Tovel (Trentino, Italy), Studi Trent. Sci. Nat. Acta Biol., 81, 147-154, 2004.

Grimm, E.: Tilia version 2.0.2 and TiliaGraph 1.12, Illinois State Museum, Research and Collection Centre, Illinois, 1992-2005.

Guiot, J.: Methodology of the last climatic cycle reconstruction in France from pollen data, Palaeogeogr. Palaeocl., 80, 49-69, 1990.

Heiri, O., Lotter, A. F., Hausmann, S., and Kienast, F.: A chironomid-based Holocene summer air temperature reconstruction from the Swiss Alps, Holocene, 13, 477-484, 2003.

Heiri, O., Filippi, M. L., and Lotter, A. F.: Lateglacial summer temperature in the Trentino area (Northern Italy) as reconstructed by fossil chironomid assemblages in Lago di Lavarone (1100 m a.s.1.), Stud Trent. Sci. Nat. Acta Geol., 82, 299-308, 2005.

Heiss, A. G., Kofler, W., and Oeggl, K.: The Ulten Valley in South Tyrol, Italy: Vegetation and Settlement History of the Area, and Macrofossil Record from the Iron Age Cult Site of St. Walburg, Palyno-Bull., 1, 63-73, 2005.

Hofstetter, S., Tinner, W., Valsecchi, V., Carraro, G., and Conedera, M.: Lateglacial and Holocene vegetation history in the Insubrian Southern Alps - New indications from a small-scale site, Veg. Hist. Archaeobot., 15, 87-98, 2006.

Huntley, B. and Birks, H. J. B.: An Atlas of Past and Present Pollen Maps for Europe: 0-13000 Years Ago, Cambridge University Press, Cambridge, 1983.

Joannin, S., Bassinot, F., Nebout, N. C., Peyron, O., and Beaudouin, C.: Vegetation response to obliquity and precession forcing during the Mid-Pleistocene Transition in Western Mediterranean region (ODP site 976), Quaternary Sci. Rev., 30, 280-297, 2011.

Joannin, S., Brugiapaglia, E., de Beaulieu, J.-L., Bernardo, L., Magny, M., Peyron, O., Goring, S., and Vannière, B.: Pollenbased reconstruction of Holocene vegetation and climate in southern Italy: the case of Lago Trifoglietti, Clim. Past, 8, 19731996, doi:10.5194/cp-8-1973-2012, 2012.

Jong, E. D., Nestor, P. A., and Pennock, D. J.: The use of magnetic susceptibility to measure long-term soil redistribution, Catena, 32, 23-35, 1998.

Jouffroy-Bapicot, I.: Palaeoenvironmental history of the Morvan mountain area (Burgundy-France), from Lateglacial to present time: Climate changes and anthropogenic impacts, $\mathrm{PhD}$ thesis, University Franche-Comté, Besançon, 456 pp., 2010.

Jump, A. S., Hunt, J. M., and Penuelas, J.: Rapid climate changerelated growth decline at the southern range edge of Fagus sylvatica, Global Change Biol., 12, 2163-2174, 2006. 
Kaltenrieder, P., Belis, C. A., Hofstetter, S., Ammann, B., Ravazzi, C., and Tinner, W.: Environmental and climatic conditions at a potential Glacial refugial site of tree species near the Southern Alpine glaciers, New insights from multiproxy sedimentary studies at Lago della Costa (Euganean Hills, Northeastern Italy), Quaternary Sci. Rev., 28, 2647-2662, 2009.

Kaltenrieder, P., Procacci, G., Vannière, B., and Tinner, W.: Vegetation and fire history of the Euganean Hills (Colli Euganei) as recorded by Lateglacial and Holocene sedimentary series from Lago della Costa (northeastern Italy), Holocene, 20, 679-695, 2010.

Löwemark, L., Chen, H. F., Yang, T. N., Kylander, M., Yu, E. F., Hsu, Y. W., Lee, T. Q., Song, S. R., and Jarvis, S.: Normalizing XRF-scanner data: A cautionary note on the interpretation of high-resolution records from organic-rich lakes, J. Asian Earth Sci., 40, 1250-1256, 2011.

Lotter, A. F.: Late-glacial and Holocene vegetation history and dynamics as shown by pollen and plant macrofossil analyses in annually laminated sediments from Soppensee, central Switzerland, Veg. Hist. Archaeobot., 8, 165-184, 1999.

Lotter, A. F., Birks, H. J. B., Eicher, U., Hofmann, W., Schwander, J., and Wick, L.: Younger Dryas and Allerod summer temperatures at Gerzensee (Switzerland) inferred from fossil pollen and cladoceran assemblages, Palaeogeogr. Palaeocl., 159, 349-361, 2000.

Magny, M.: Holocene climate variability as reflected by midEuropean lake-level fluctuations and its probable impact on prehistoric human settlements, Quatern. Int., 113, 65-79, 2004.

Magny, M. and Haas, J. N.: A major widespread climatic change around $5300 \mathrm{cal} \mathrm{yr} \mathrm{BP}$ at the time of the Alpine Iceman, J. Quaternary Sci., 19, 423-430, 2004.

Magny, M., Bégeot, C., Guiot, J., and Peyron, O.: Contrasting patterns of hydrological changes in Europe in response to Holocene climate cooling phases, Quaternary Sci. Rev., 22, 1589-1596, 2003.

Magny, M., De Beaulieu, J. L., Drescher-Schneider, R., Vannière, B., Walter-Simonnet, A. V., Millet, L., Bossuet, G., and Peyron, O.: Climatic oscillations in central Italy during the Last GlacialHolocene transition: the record from Lake Accesa, J. Quaternary Sci., 21, 311-320, 2006a.

Magny, M., Leuzinger, U., Bortenschlager, S., and Haas, J. N.: Tripartite climate reversal in Central Europe 5600-5300 years ago, Quaternary Res., 65, 3-19, 2006 b.

Magny, M., Vannière, B., de Beaulieu, J., Bégeot, C., Heiri, O., Millet, L., Peyron, O., and Walter-Simonnet, A. V.: Early-Holocene climatic oscillations recorded by lake-level fluctuations in westcentral Europe and in central Italy, Quaternary Sci. Rev., 26, 1951-1964, 2007.

Magny, M., Galop, D., Bellintani, P., Desmet, M., Didier, J., Haas, J. N., Martinelli, N., Pedrotti, A., Scandolari, R., Stock, A., and Vannière, B.: Late-Holocene climatic variability south of the Alps as recorded by lake-level fluctuations at Lake Ledro, Trentino, Italy, Holocene, 19, 575-589, 2009.

Magny, M., Peyron, O., Sadori, L., Ortu, E., Zanchetta, G., Vannière, B., and Tinner, W.: Contrasting patterns of precipitation seasonality during the Holocene in the south- and northcentral Mediterranean, J. Quaternary Sci., 27, 290-296, 2011.
Magny, M., Joannin, S., Galop, D., Vannière, B., Haas, J. N., Basseti, M., Bellintani, P., Scandolari, R., and Desmet, M.: Holocene palaeohydrological changes in the northern Mediterranean borderlands as reflected by the lake-level record of Lake Ledro, northeastern Italy, Quaternary Res., 77, 382-396, 2012.

Mayewski, P. A., Rohling, E. E., Stager, J. C., Karlén, W., Maasch, K. A., Meeker, L. D., Meyerson, E. A., Gasse, F., Kreveld, S. V., Holmgren, K., Lee-Thorp, J., Rosqvist, G., Rack, F., Staubwasser, M., Schneider, R. R., and Steig, E. J.: Holocene climate variability, Quaternary Res., 62, 243-255, 2004.

Mazier, F.: Modélisation de la relation entre pluie pollinique actuelle, végétation et pratiques pastorales en moyenne montagne (Pyrénées et Jura), PhD thesis, Université de FrancheComté, Besançon, 243 pp., 2006.

Miller, G. H., Brigham-Grette, J., Alley, R. B., Anderson, L., Bauch, H. A., Douglas, M. S. V., Edwards, M. E., Elias, S. A., Finney, B. P., Fitzpatrick, J. J., Funder, S. V., Herbert, T. D., Hinzman, L. D., Kaufman, D. S., MacDonald, G. M., Polyak, L., Robock, A., Serreze, M. C., Smol, J. P., Spielhagen, R., White, J. W. C., Wolfe, A. P., and Wolff, E. W.: Temperature and precipitation history of the Arctic, Quaternary Sci. Rev., 29, 1679-1715, 2010.

Monegato, G., Ravazzi, C., Donegana, M., Pini, R., Calderoni, G., and Wick, L.: Evidence of a two-fold glacial advance during the last glacial maximum in the Tagliamento end moraine system (eastern Alps), Quaternary Res., 68, 284-302, 2007.

Moore, P. D., Webb, J. A., and Collinson, M. E.: Pollen Analysis, Blackwell Scientific Publications, London, 1991.

Nicolussi, K., Kaufmann, M., Melvin, T. M., van der Plicht, J., Schiessling, P., and Thurner, A.: A 9111 year long conifer treering chronology for the European Alps: a base for environmental and climatic investigations, Holocene, 19, 909-920, 2009.

Olsen, J., Björck, S., Leng, M. J., Gudmundsdóttir, E. R., Odgaard, B. V., Lutz, C. M., Kendrick, C. P., Andersen, T. J., and Seidenkrantz, M.: Lacustrine evidence of Holocene environmental change from three Faroese lakes: a multiproxy XRF and stable isotope study, Quaternary Sci. Rev., 29, 2764-2780, 2010.

Peyron, O., Guiot, J., Cheddadi, R., Tarasov, P., Reille, M., de Beaulieu, J. L., Bottema, S., and Andrieu, V.: Climatic reconstruction in Europe for 18,000 yr B.P. from pollen data, Quaternary Res., 49, 183-196, 1998.

Peyron, O., Goring, S., Dormoy, I., Kotthoff, U., Pross, J., de Beaulieu, J. L., Drescher-Schneider, R., Vannière, B., and Magny, M.: Holocene seasonality changes in central Mediterranean reconstructed from Lake Accesa and Tenaghi Philippon pollen sequences, Holocene, 21, 131-146, 2011.

Peyron, O., Magny, M., Goring, S., Joannin, S., de Beaulieu, J.L., Brugiapaglia, E., Sadori, L., Garfi, G., Kouli, K., Ioakim, C., and Combourieu-Nebout, N.: Contrasting patterns of climatic changes during the Holocene in the Central Mediterranean (Italy) reconstructed from pollen data, Clim. Past Discuss., 8, 58175866, doi:10.5194/cpd-8-5817-2012, 2012.

Pini, R.: A high-resolution Late-Glacial - Holocene pollen diagram from Pian di Gembro (Central Alps, Northern Italy), Veg. Hist. Archaeobot., 11, 251-262, 2002.

Pinton, V. and Carrara, N.: La collezione della palafitta di Ledro del Museo di Antropologia dell'Università di Padova: ricostruzione del paleoambiente, Annali dell'Università degli Studi di Ferrara - Museologia Scientifica e Naturalistica, Special Volume, Università degli Studi di Ferrara, 11-14, 2007. 
Ravazzi, C.: Late Quaternary history of spruce in southern Europe, Rev. Palaeobot. Palynol., 120, 131-177, 2002.

Reille, M.: Pollen et Spores d'Europe et d'Afrique du nord, Laboratoire de Botanique Historique et Palynologie, Université d'AixMarseille, Marseille, 1992-1998.

Reimer, P. J., Baillie, M. G .L., Bard, E., Bayliss, A., Beck, J. W., Blackwell, P. G., Ramsey, C. B., Buck, C. E., Burr, G. S., Edwards, R. L., Friedrich, M., Grootes, P. M., Guilderson, T. P., Hajdas, I., Heaton, T. J., Hogg, A. G., Hughen, K. A., Kaiser, K. F., Kromer, B., McCormac, F. G., Manning, S. W., Reimer, R. W., Richards, D. A., Southon, J. R., Talamo, S., Turney, C. S. M., van der Plicht, J., and Weyhenmeye, C. E.: INTCAL09 and MARINE09 radiocarbon age calibration curves, 050,000 years cal BP, Radiocarbon, 51, 1111-1150, 2009.

Roberts, N., Brayshaw, D., Kuzucuoğlu, C., Perez, R., and Sadori, L.: The mid-Holocene climatic transition in the Mediterranean: Causes and consequences, Holocene, 21, 3-13, 2011.

Rottoli, M. and Castiglioni, E.: Prehistory of plant growing and collecting in northern Italy, based on seed remains from the early Neolithic to the Chalcolithic (c. 5600-2100 cal B.C.), Veg. Hist. Archaeobot., 18, 91-103, 2009.

Seppä, H., Alenius, T., Bradshaw, R. H. W., Giesecke, T., Heikkila, M., and Muukkonen, P.: Invasion of Norway spruce (Picea abies) and the rise of the boreal ecosystem in Fennoscandia, J. Ecol., 97, 629-640, 2009.

Simonneau, A., Chapron, E., Vannière, B., Wirth, S. B., Gilli, A., Di Giovanni, C., Anselmetti, F. S., Desmet, M., and Magny, M.: Mass-movement and flood-induced deposits in Lake Ledro, southern Alps, Italy: implications for Holocene palaeohydrology and natural hazards, Clim. Past, 9, 825-840, doi:10.5194/cp-9825-2013, 2013.

Sjögren, P., Knaap, W. V. D., Huusko, A., and Leeuwen, J. F. V.: Pollen productivity, dispersal, and correction factors for major tree taxa in the Swiss Alps based on pollen-trap results, Rev. Palaeobot. Palynol., 152, 200-210, 2008.

Spötl, C., Nicolussi, K., Patzelt, G., Boch, R., and Team, D.: Humid climate during deposition of sapropel 1 in the Mediterranean Sea: Assessing the influence on the Alps, Global Planet. Change, 71, 242-248, 2010.

Stockmarr, J.: Tablets with spores used in absolute pollen analysis, Pollen et Spores, 13, 615-621, 1971.

Thompson, R. and Oldfield, F.: Environmental Magnetism, Allen \& Unwin, London, 1986.

Tinner, W. and Vescovi, E.: Treeline ecology and oscillations in the Alps from the Pleniglacial to the present, Studi Trent. Sci. Nat. Acta Geol., 82, 7-15, 2005.

Tinner, W., Hubschmid, P., Wehrli, M., Ammann, B., and Conedera, M.: Long-term forest fire ecology and dynamics in southern Switzerland, J. Ecol., 87, 273-289, 1999.

Tinner, W., Lotter, A. F., Ammann, B., Conedera, M., Hubschmid, P., Leeuwen, J. F. N. V., and Wehrli, M.: Climatic change and contemporaneous land-use phases north and south of the Alps 2300 BC to 800 AD, Quaternary Sci. Rev., 22, 1447-1460, 2003.

Tweddle, J. C., Edwards, K. J., and Fieller, N. R. J.: Multivariate statistical and other approaches for the separation of cereal from wild Poaceae pollen using a large Holocene dataset, Veg. Hist. Archaeobot., 14, 15-30, 2005.
Valsecchi, V. and Tinner, W.: Vegetation responses to climatic variability in the Swiss Southern Alps during the Misox event at the early- mid Holocene transition, J. Quaternary Sci., 25, 1248 1258, 2010.

Valsecchi, V., Tinner, W., Finsinger, W., and Ammann, B.: Human impact during the Bronze Age on the vegetation at Lago Lucone (northern Italy), Veg. Hist. Archaeobot., 15, 99-113, 2006.

Valsecchi, V., Finsinger, W., Tinner, W., and Ammann, B.: Testing the influence of climate, human impact and fire on the Holocene population expansion of Fagus sylvatica in the southern Prealps (Italy), Holocene, 18, 603-614, 2008.

Valsecchi, V., Carraro, G., Conedera, M., and Tinner, W.: LateHolocene vegetation and land-use dynamics in the Southern Alps (Switzerland) as a basis for nature protection and forest management, Holocene, 20, 483-495, 2010.

Van der Knaap, W., Leeuwen, J. F. V., Finsinger, W., Gobet, E., Pini, R., Schweizer, A., Valsecchi, V., and Ammann, B.: Migration and population expansion of Abies, Fagus, Picea, and Quercus since 15000 years in and across the Alps, based on pollen-percentage threshold values, Quaternary Sci. Rev., 24, 645-680, 2005.

Vannieère, B., Bossuet, G., Walter-Simonnet, A. V., Gauthier, E., Barral, P., Petit, C., Buatier, M., and Daubigney, A.: Land use change, soil erosion and alluvial dynamic in the lower Doubs Valley over the 1st millenium AD (Neublans, Jura, France), J. Archaeol. Res., 30, 1283-1299, 2003.

Vannière, B., Power, M. J., Roberts, N., Tinner, W., Carrion, J., Magny, M., Bartlein, P., Colombaroli, D., Daniau, A. L., Finsinger, W., Gil-Romera, G., Kaltenrieder, P., Pini, R., Sadori, L., Turner, R., Valsecchi, V., and Vescovi, E.: CircumMediterranean fire activity and climate changes during the mid-Holocene environmental transition (8500-2500 cal. BP), Holocene, 21, 53-73, 2011.

Vannière, B., Magny, M., Joannin, S., Simonneau, A., Wirth, S. B., Hamann, Y., Chapron, E., Gilli, A., Desmet, M., and Anselmetti, F. S.: Orbital changes, variation in solar activity and increased anthropogenic activities: controls on the Holocene flood frequency in the Lake Ledro area, Northern Italy, Clim. Past Discuss., 8, 4701-4744, doi:10.5194/cpd-8-4701-2012, 2012.

Vescovi, E., Ravazzi, C., Arpenti, E., Finsinger, W., Pini, R., Valsecchi, V., Wick, L., Ammann, B., and Tinner, W.: Interactions between climate and vegetation during the Lateglacial period as recorded by lake and mire sediment archives in Northern Italy and Southern Switzerland, Quaternary Sci. Rev., 26, 1650-1669, 2007.

Vescovi, E., Ammann, B., Ravazzi, C., and Tinner, W.: A new Late-glacial and Holocene record of vegetation and fire history from Lago del Greppo, northern Apennines, Italy, Veg. Hist. Archaeobot., 19, 219-233, 2010.

Whitlock, C., Briles, C. E., Fernandez, M. C., and Gage, J.: Holocene vegetation, fire and climate history of the Sawtooth Range, central Idaho, USA, Quaternary Res., 75, 114-124, 2011.

Wick, L.: Vegetational response to climatic changes recorded in Swiss Late Glacial lake sediments, Palaeogeogr. Palaeocl., 159, 231-250, 2000.

Wick, L. and Möhl, A.: The mid-Holocene extinction of silver fir (Abies alba) in the Southern Alps: a consequence of forest fires? Palaeobotanical records and forest simulations, Veg. Hist. Archaeobot., 15, 435-444, 2006. 
Wiersma, A. P. and Jongma, J. I.: A role for icebergs in the $8.2 \mathrm{ka}$ climate event, Clim. Dynam., 35, 535-549, 2010.

Yu, S., Colman, S. M., Lowell, T. V., Milne, G. A., Fisher, T. G., Breckenridge, A., Boyd, M., and Teller, J. T.: Freshwater Outburst from Lake Superior as a Trigger for the Cold Event 9300 Years Ago, Science, 328, 1262-1266, 2010.

Zanchetta, G., Drysdale, R. N., Hellstrom, J. C., Fallick, A. E., Isola, I., Gagan, M. K., and Pareschi, M. T.: Enhanced rainfall in the Western Mediterranean during deposition of sapropel S1: stalagmite evidence from Corchia cave (Central Italy), Quaternary Sci. Rev., 26, 279-286, 2007.
Zanchetta, G., Giraudi, C., Sulpizio, R., Magny, M., Drysdale, R. N., and Sadori, L.: Constraining the onset of the Holocene "Neoglacial" over the central Italy using tephra layers, Quaternary Res., 78, 236-247, 2012.

Zhao, C., Yu, Z., Ito, E., and Zhao, Y.: Holocene climate trend, variability, and shift documented by lacustrine stable-isotope record in the northeastern United States, Quaternary Sci. Rev., 29, 1831-1843, 2010. 